\title{
The Surprising Resilience of the Patent System ${ }^{1}$
}

\author{
Mark A. Lemley ${ }^{2}$
}

The patent system seems in the midst of truly dramatic change. The last twenty years have seen the rise of a new business model - the patent troll - that grew to become a majority of all patent lawsuits. They have seen a significant expansion in the number of patents granted and a fundamental change in the industries in which those patents are filed. They have seen the passage of the most important legislative reform in the last sixty years, a law that reoriented legal challenges to patents away from courts and toward the Patent and Trademark Office (PTO). And they have seen remarkable changes in nearly every important legal doctrine, from patent eligibility to obviousness to infringement to remedies.

These changes have prompted alarm in a number of quarters. From the 1990 s to the 2000s, as the number of patents and patent troll suits skyrocketed, technology companies and academics worried about the "crisis" in the patent system - a crisis of overprotection that might interfere with rather than promote innovation. ${ }^{3}$ By 2015 , as patent reform took effect and the Supreme Court undid many of the Federal Circuit's expansions of patent rights, it was

1 (C) 2016 Mark A. Lemley.

2 William H. Neukom Professor, Stanford Law School; partner, Durie Tangri LLP.

Thanks to Tun-Jen Chiang, Colleen Chien, Robin Feldman, Rose Hagan, Erik Oliver, Lisa Ouellette, and members of the San Diego Intellectual Property Law Association for comments on an earlier draft.

3 See, e.g., Dan L. Burk \& Mark A. Lemley, The Patent Crisis and How the Courts Can Solve It (2009); Adam Jaffe \& Josh Lerner, Innovation and Its Discontents (2004); James Bessen \& Michael J. Meurer, Patent Failure: How Judges, Lawyers, and Bureaucrats Put Innovation at Risk (2008); Internet Association letter to Congress supporting patent reform, July 16, 2015, available at http://internetassociation.org/wpcontent/uploads/2015/07/Letter_from_Internet_CEOs_InnovationAct.pdf 
patent owners who were speaking of a crisis in the patent system - a crisis of underprotection that might leave innovators without adequate protection. ${ }^{4}$ Depending on one's perspective, then, the sky seems to have been falling on the patent system for some time.

Despite the undeniable significance of these changes in both directions, something curious has happened to the fundamental characteristics of the patent ecosystem during this period: very little. Whether we look at the number of patent applications filed, the number of patents issued, the number of lawsuits filed, the patentee win rate in those lawsuits, or the market for patent licenses, the data show very little evidence that patent owners and challengers are behaving differently because of changes in the law. The patent system, then, seems surprisingly resilient to changes in the law. This is a puzzle. In this article, I document this phenomenon and give some thought to why the fundamental characteristics of the patent system seem resistant to even major changes in patent law and procedure. The results pose some profound questions not only for efforts at patent reform but for the role of the patent system in society as a whole.

In Part I I briefly review the changes to the patent system in the past 35 years. In Part II, I discuss the pendulum swings between perceived overprotection and perceived underprotection and the concerns lawyers have raised in both directions. In Part III, I present

\footnotetext{
4 See, e.g., Hon. Maureen K. Ohlhausen, Patent Rights in a Climate of IPR Skepticism (working paper 2016); John R. Harris, The Patent System is Under Assault - Startups, Should You Care? Ten Things About Patents That Startups Need to Consider, 44 AIPLA Q.J. 27 (2016); Adam Mossoff, The Trespass Fallacy in Patent Law, 65 Fla. L. Rev. 1687 (2013); Gene Quinn, Fixing the Patent System Requires a Return to Strong Patent Rights, IP Watchdog, Sept. 15, 2015, http://www.ipwatchdog.com/2015/09/15/fixing-thepatent-system-requires-a-return-to-strong-patent-rights/id=61684/; David Kappos, An Open Letter to Abraham Lincoln From David Kappos, http://www.managingip.com/Blog/3334558/Guest-post-An-openletter-to-Abraham-Lincoln-from-David-Kappos.html.
} 
evidence of the resilience of the patent system. Finally, in Part IV, I offer some possible explanations for this surprising result.

\section{A Tumultuous Four Decades}

In many respects it is hard to overstate how much the patent system has changed in the past few decades. In 1984, the PTO issued 67,200 utility patents. In 2014 , the PTO issued 300,678 , nearly five times as many. ${ }^{5}$ The patents issued in the 1970 s were overwhelmingly for mechanical inventions. ${ }^{6}$ By the 1990 s, computer-related inventions had grown and mechanical inventions had declined, but mechanical inventions were still a plurality of all patents issued. ${ }^{7}$ By the 2000s, half of all patents were granted in the IP industries, and mechanical patents had receded to a much smaller share. ${ }^{8}$

Patent litigation has changed as well. In 1980, there were fewer than 800 patent lawsuits filed. By 2010 there were 2,769 suits, a $350 \%$ increase. $^{9}$ The number of suits is even higher today, reaching a peak of 6,114 suits in 2013 , but a 2011 change in the way suits are filed makes it difficult to compare data from before 2011 to more recent data.

5 http://www.uspto.gov/web/offices/ac/ido/oeip/taf/h_counts.htm.

6 John R. Allison \& Mark A. Lemley, The Growing Complexity of the U.S. Patent System, 82 B.U. L. Rev. 77 (2002).

7 Id.

8 See, e.g., Mark A. Lemley \& Bhaven Sampat, Is the Patent Office a Rubber Stamp?, 58 Emory L.J. 181 (2008).

9 https://law.lexmachina.com/. The IP Watchdog graph includes some duplicate cases (such as a patent infringement lawsuit and a declaratory judgment action filed by opposing parties on the same patent in different districts) that Lex Machina has cleaned in its data. Because Lex Machina data only goes back to 2000, I have used IP Watchdog data for 1980. It is worth noting that it too likely modestly overstates the number of patent lawsuits. 


\section{Figure 1}

\section{Patent Cases Commenced, 1980 - 2012}

6000

5000

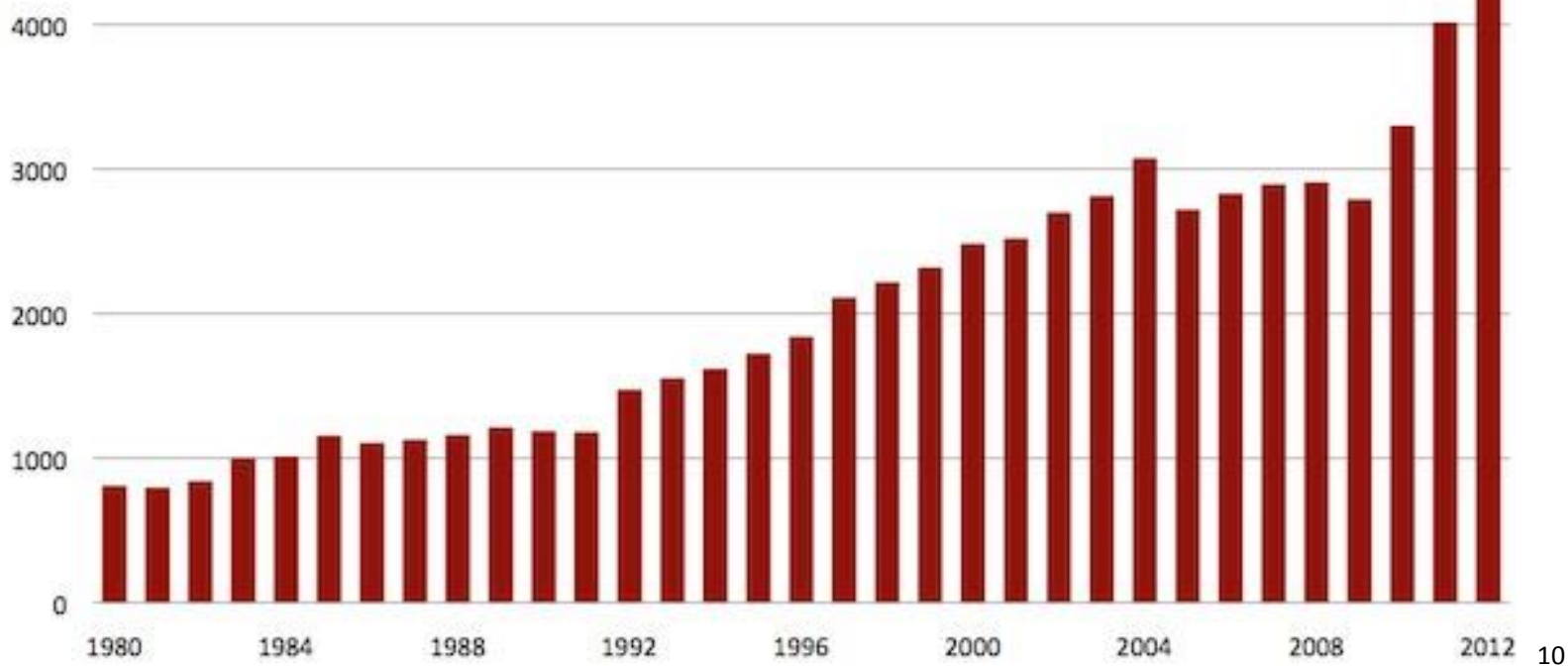

The last quarter century also saw dramatic changes in who filed those suits and where.

In 1990, there was a single active litigant who could be described as a patent troll - Jerome Lemelson. ${ }^{11}$ The model gained in popularity during the $1990 \mathrm{~s}$ and $2000 \mathrm{~s}^{12}$ By the 2010s,

10 IP Watchdog, http://www.ipwatchdog.com/2013/04/09/the-rise-of-patent-litigation-in-america1980-2012/id=38910/

11 See, e.g., Adam Goldman, A Great Inventor, or a Big Fraud, L.A. Times, Aug. 21, 2005, http://articles.latimes.com/2005/aug/21/news/adna-patent21. For discussion of Lemelson's role in the rise of patent trolls, see Mark A. Lemley \& Kimberly A. Moore, Ending Abuse of Patent Continuations, 84 B.U. L. Rev. 63 (2004).

12 Brian J. Love, An Empirical Study of Patent Litigation Timing: Could a Patent Term Reduction Decimate Trolls Without Harming Innovators?, 161 U. Pa. L. Rev. 1639 (2013). 
depending on how one defines a patent troll, a majority of all patent lawsuits were filed by patent trolls or other plaintiffs that do not make products. ${ }^{13}$

The rise of forum shopping has concentrated patent suits in just a few districts viewed as plaintiff-friendly. ${ }^{14}$ The majority of suits in 2015 were filed in just two districts - the Eastern District of Texas and the District of Delaware. ${ }^{15}$ Indeed, just two judges out of the 650 federal district judges nationwide hear almost half of the nation's patent cases.

13 Colleen V. Chien, Patent Assertion Entities, Presentation to the DOJ/FTC Hearing on PAEs (Dec. 10, 2012) http://papers.ssrn.com/sol3/papers.cfm?abstract id=2187314 (finding that trolls filed 62\% of suits); Christopher A. Cotropia, Jay P. Kesan \& David L. Schwartz, Unpacking Patent Assertion Entities, 99 MINN. L. REV. 649, 655 (2014) (filed that trolls file a bare majority of suits, using a more conservative definition); Robin Feldman, Tom Ewing \& Sara Jeruss, The AIA 500 Expanded: The Effects of Patent Monetization Entities, 17 UCLA J.L. \& TECH. 1, 42 (2013), http://www.lawtechjournal.com/articles/2013/041024-Feldman.pdf [http://perma.cc/9RET-3ERZ].

14 See, e.g., Daniel M. Klerman \& Greg Reilly, Forum Selling, _ S. Cal. L. Rev. _ (forthcoming 2016) (documenting the efforts of the Eastern District of Texas to attract patent troll suits).

15 www.lexmachina.com (viewed December 10, 2015) (finding that 2978 of 5611 suits filed so far in 2015 were filed in ED Tex or D Del). 


\section{Figure 2}

\section{The Busiest Patent Judges}

Six federal judges presided over more than 100 patent cases last year. Two of Texas' Eastern District judges oversaw the largest share - more than $40 \%$ of all 5,549 new patent cases filed in 2015. The other four judges with triple-digit caseloads are seated in Delaware.

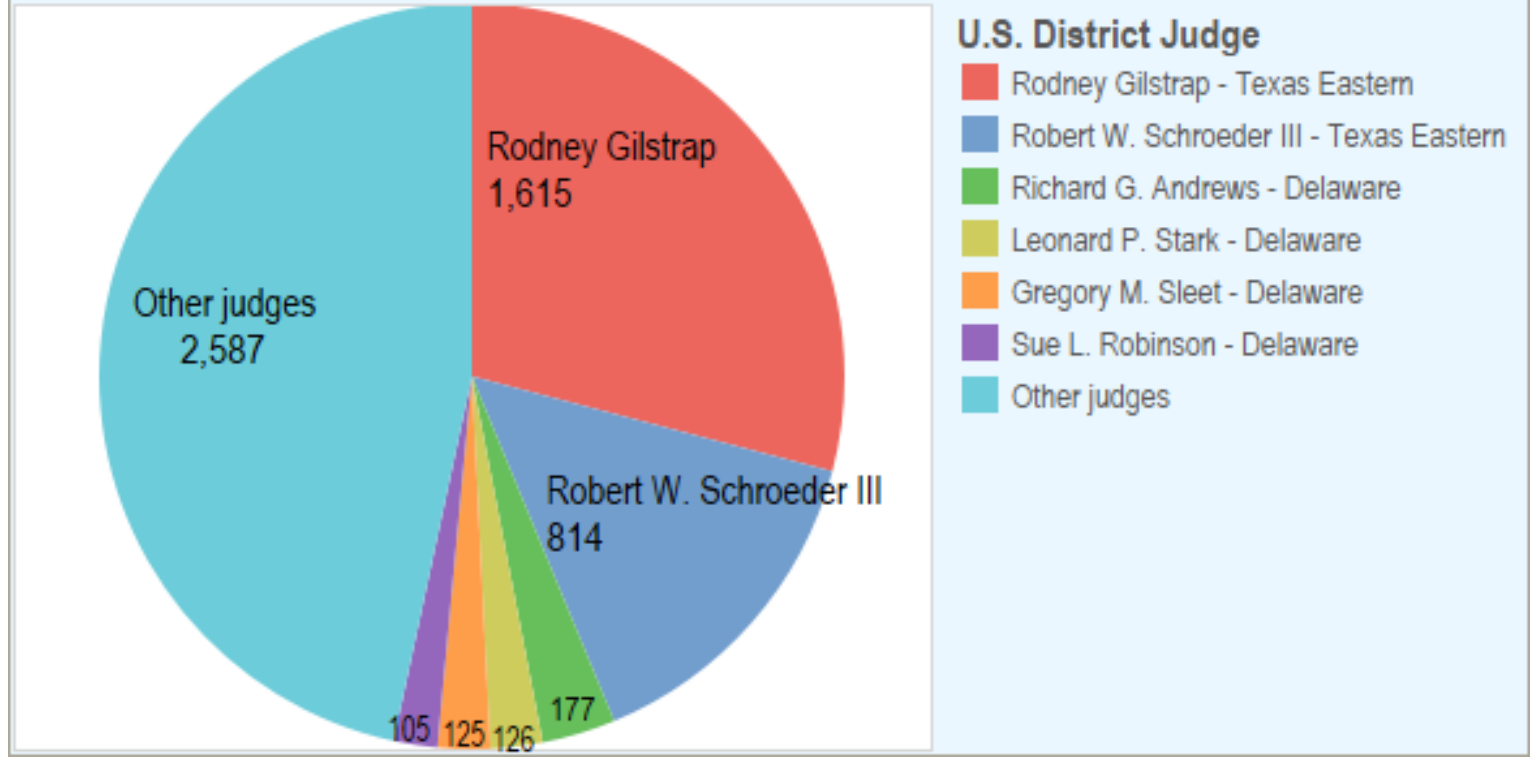

By contrast, those same districts in 2000 accounted for only 273 of 2523 suits, just over $10 \%{ }^{17}$

More recently, the passage of the America Invents Act has led to an explosion of "inter partes review" (IPR) proceedings in which parties challenge the validity of a patent at the PTO. There have been over 4000 IPRs instituted since $2011 .{ }^{18}$ IPR challenges aren't replacing patent

16 Ryan Davis, Patent Suit Flood Pressuring East Texas Bench, Chief Says, IP360, February 10, 2016, http://www.law360.com/ip/articles/757022?nl pk=3fa8c13f-2809-474e-b3e5-

23795e52e060\&utm source=newsletter\&utm medium=email\&utm campaign=ip.

17

Id.

18 https://law.lexmachina.com/court/ptab (documenting 4,593 instituted IPR proceedings as of February 24, 2016). Many more IPR proceedings are filed but not institute by the Board. 
litigation in district court, but they often lead to stays of district court litigation while the validity of the patent is being considered, and frequently end up resolving the suit. ${ }^{19}$

The process of patent litigation also looks very different than it did in the past. The past forty years have seen the rise of the jury trial, from less than $10 \%$ of all patent cases in the 1970 s to over $70 \%$ of patent cases today. ${ }^{20}$ That in turn has changed the pretrial procedures in all cases, prompting pretrial motions to dismiss and for summary judgment. The 1990s saw the institution of a pre-trial proceeding - the Markman hearing - to construe the claims of the patent. It is fair to say that the basic focus of almost every patent case today is driven by these two procedural changes. Patent litigation is usually aimed either at the Markman hearing or at the question of whether the plaintiff will get to trial.

The overall effect of these changes has been that the patent law in 2016, both substantive and procedural, would in many respects be unrecognizable to a patent lawyer from the 1970s. The patents look different, the scale of the system looks different, and the litigation process looks different. As we will see in the next part, the substantive law looks different too.

\section{Sounding the Alarm}

\section{A. The "Patent Crisis" and How the Courts Solved It}

After the Federal Circuit was created in 1982 with a mission to strengthen patent rights, it did just that in the 1980s and 1990s, holding software and business methods eligible for

19 See, e.g., Brian J. Love, Inter Partes Review: An Early Look at the Numbers, 81 U. Chi. L. Rev. Dialogue 93 (2014); https://lexmachina.com/media/press/2015-report-on-ptab-litigation/.

20 Mark A. Lemley, Why Do Juries Decide If Patents Are Valid?, 99 Va. L. Rev. 1673 (2013); Herbert F. Schwartz, Fed. Jud. Ctr., Patent Law and Practice 130 (2d. ed. 1995) (tabulating data through 1994) (documenting the rise of jury trials from $2.5 \%$ of patent cases in 1940 to over $70 \%$ in 1995). 
patenting, ${ }^{21}$ changing the law of obviousness to uphold more patents, ${ }^{22}$ curtailing claims of inequitable conduct and patent misuse, ${ }^{23}$ expanding damages, ${ }^{24}$ making it easier to show that the defendant was a willful infringer, ${ }^{25}$ and making it easier to get an injunction. ${ }^{26}$ It raised the validity rate of patents in appellate decisions from $35 \%$ to $55 \% .^{27}$

The dramatic expansion in the strength, scope, and enforcement of patent rights in the 1980 s and 1990 s let to a chorus of calls for reform. The Federal Trade Commission issued an influential report in 2003 calling for significant changes to the patent system to prevent it from

21 See, e.g., In re Alappat, 33 F.3d 1526 (Fed. Cir. 1994) (en banc); State Street Bank \& Trust Co v. Signature Fin. Servs., 149 F.3d 1368 (Fed. Cir. 1998).

22 See, e.g., R. Polk Wagner, The Federal Circuit and Patentability: An Empirical Assessment of the Law of Obviousness, 85 Tex. L. Rev. 2051 (2007); Christopher A. Cotropia, Patent Law Viewed Through an Evidentiary Lens: The "Suggestion Test" as a Rule of Evidence, 2006 B.Y.U. L. Rev. 1517; Christopher A. Cotropia, Nonobviousness and the Federal Circuit: An Empirical Analysis of Recent Case Law, 82 Notre Dame L. Rev. 911 (2006).

23 See, e.g., Kingsdown Med. Consultants, Inc. v. Hollister, Inc., 863 F.2d 867 (Fed. Cir. 1988) (en banc); Mallinckrodt, Inc. v. Medipart, Inc., 976 F.2d 700 (Fed. Cir. 1992).

24 See, e.g., Rite-Hite Corp. v. Kelly, 56 F.3d 1538 (Fed. Cir. 1995) (en banc); King Instruments v. Perego, 65 F.3d 941 (Fed. Cir. 1995). For a discussion of the problems with this expansion, see, e.g., Brian J. Love, Patentee Overcompensation and the Entire Market Value Rule, 60 Stan. L. Rev. 263 (2007); Brian J. Love, The Misuse of Reasonable Royalty Damages as a Patent Infringement Deterrent, 74 Mo. L. Rev. 909 (2009); Daralyn J. Durie \& Mark A. Lemley, A Structured Approach to Calculating Reasonable Royalties, 14 Lewis \& Clark L. Rev. 627 (2010).

25 See, e.g., Underwater Devices v. Morrison-Knudsen Co., 717 F.2d 1380 (Fed. Cir. 1983).

26 Before the Supreme Court decision in eBay v. MercExchange in 2006, the Federal Circuit has never denied a permanent injunction. See, e.g., Colleen V. Chien \& Mark A. Lemley, Patent Holdup, the ITC, and the Public Interest, 98 Cornell L. Rev. 1 (2012). The court also expanded the availability of preliminary injunctions during that period. H.H. Robertson Co. v. United Steel Deck Inc., 820 F.2d 384 (Fed. Cir. 1987).

27 Compare Gloria Koenig, Patent Invalidity: A Statistical and Substantive Analysis 3-4 to 3-10 (rev. ed. 1980) (finding patents were held valid only 35\% of the time between 1953 and 1978) with John R. Allison \& Mark A. Lemley, Empirical Evidence on the Validity of Litigated Patents, 26 AIPLA Q.J. 185 (1998) (finding that patents were held valid 54\% of the time between 1989 and 1996) and Donald R. Dunner et al, A Statistical Look at the Federal Circuit's Patent Decisions, 1982-1994, 5 Fed. Cir. B.J. 151 (1995) (finding that patents were held valid 57\% of the time between 1982 and 1994). 
becoming a drag on rather than a benefit to innovation. ${ }^{28}$ That same year, a study committee of the National Academy of Sciences issued a series of recommendations for reform that became the basis for proposed legislation in Congress starting in 2005.

Academics also spoke up to point out the risks of a seemingly ever-expanding patent system. Adam Jaffe and Josh Lerner, in a 2004 book called "Innovation and Its Discontents: How Our Broken Patent System is Endangering Innovation, and What to Do About It," argued that changes to the patent system in the 1980s and 1990s had turned the patent system from a driver of innovation into a regulatory burden on innovative companies. ${ }^{29}$ Four years later, Jim Bessen and Mike Meurer published "Patent Failure: How Judges, Lawyers, and Bureaucrats Put Innovation at Risk." ${ }^{30}$ They collected evidence suggesting that the modern patent system was a net drag on innovation in almost every industry. Only in the life sciences industries were patents actually contributing to economic value. ${ }^{31}$ In other areas, the growth of patent trolls and the expanded scope of patent claims meant that the most innovative companies were overwhelmingly patent defendants, not plaintiffs. ${ }^{32}$ Both books suggested a number of proposed patent reforms.

28 Federal Trade Commission, To Promote Innovation: The Proper Balance of Competition and Patent Law and Policy (2003), https://www.ftc.gov/reports/promote-innovation-proper-balance-competitionpatent-law-policy (proposing ten changes to rein in excessive patent protection).

Id. at

Id. at 
Michele Boldrin and David Levine went even further. In their book "Against Intellectual Monopoly," they argued that the entire patent system was unnecessary to drive innovation, and the fact that it restricted market freedom made innovation less likely. ${ }^{33}$

Even I got in the act. In a 2009 book titled "The Patent Crisis and How the Courts Can Solve It," Dan Burk and I argued that the patent system was in crisis. ${ }^{34}$ We pointed out that different industries experience the patent system very differently, and that many of the problems with the patent system came from the IT industries but did not apply in other industries like pharmaceuticals. ${ }^{35}$ Unlike other commentators, we did not recommend legislative reform, instead focusing on the power of the courts to apply unitary rules with sensitivity to the needs of different industries. ${ }^{36}$

These are only a few prominent examples of a wave of complaints about the patent system in the last decade. ${ }^{37}$ These complaints shared a worry that two decades of strengthening patents had led to a wave of bad patents approved by the PTO in the 1990s and asserted in the 2000s; to a pervasive problem of patent holdup as companies faced hundreds of suits, each with the potential to shut down its core product; ${ }^{38}$ and to a flood of suits by non-

\footnotetext{
33 Michele Boldrin \& David K. Levine, Against Intellectual Monopoly (2006).

34 Dan L. Burk \& Mark A. Lemley, The Patent Crisis and How the Courts Can Solve It (2009). Accord Dan L. Burk \& Mark A. Lemley, Policy Levers in Patent Law, 89 Va. L. Rev. 1575 (2003); Peter S. Menell, A Method for Reforming the Patent System, 13 Mich. Telecomm. \& Tech. L. Rev. 487 (2007).

35 Id.

36 Id.

37 See, e.g., Shivan Mehta, Patent Reform Act of 2010: The Time for Change Is Now, 7 Okla. J. L. \& Tech. 56 (2011); Mozelle W. Thompson \& Susan Stark DeSanti, Forward, 19 Berkeley Tech. L.J. 857 (2004) (describing a series of articles and industry perspectives as reflecting "a consensus that patent reforms are needed"); Jay P. Kesan \& Andres A. Gallo, The Political Economy of the Patent System, 87 N.C. L. Rev. 1341 (2009).

38 Mark A. Lemley \& Carl Shapiro, Patent Holdup and Royalty Stacking, 85 Tex. L. Rev. 1991 (2007).
} 
practicing entities or "patent trolls" that took advantage of plaintiff-friendly rules to extract more money than they deserved.

\section{B. The New Worry: Weakening the Patent System}

The pendulum began to swing back in the 2000s as the increase in the number of patent troll suits prompted calls for reform. ${ }^{39}$ Congress began considering patent reform in 2005, ultimately passing the America Invents Act in 2011. The AIA didn't change much about patent litigation, but it created the IPR procedure and also changed the way we allocate patents to competing claimants, awarding patents to the first inventor to file a patent application rather than the first to invent. But the Supreme Court made a number of changes in that period, mostly in the direction of weakening patent rights. It made it easier to invalidate a patent as obvious. ${ }^{40}$ It made it easier to file a declaratory judgment action challenging a patent. ${ }^{41}$ It held that winning a patent suit doesn't automatically justify an injunction. ${ }^{42}$ It made it easier for prevailing defendants to recover their attorneys' fees. ${ }^{43}$ And in a series of cases it has held that patents are not appropriate for laws of nature, natural phenomena, and abstract ideas, casting

39 See, e.g., Troy A. Groetken, Timothy R. Holbrook, Sean Seymore, \& Donald L. Zuhn, Jr., The Pendulum Swings Back: The Impact of Recent SCOTUS and Federal Circuit Cases, 6 Nw. J. Tech. \& Intell. Prop. 331, 332 (2008).

40 KSR Int'I Co. v. Teleflex Inc., 550 U.S. 398 (2007).

41 Medlmmune, Inc. v. Genentech, Inc., 549 U.S. 118 (2007).

42 eBay, Inc. v. MercExchange LLC, 547 U.S. 388 (2006).

43 Octane Fitness LLC v. Icon Health \& Fitness, Inc., 134 S.Ct. 1749 (2014). 
significant doubt on the validity of many business method, software, genetics, and medical diagnostic patents. ${ }^{44}$

The Federal Circuit too made a number of changes during this period that weakened patent rights. It cut back dramatically on the "doctrine of equivalents," which allowed patentees to expand the reach of their patent claims. ${ }^{45}$ It backtracked on willfulness, raising the standard of proof and eliminating the requirement that defendants obtain an opinion of counsel. ${ }^{46}$ It took some steps to restrict forum-shopping, ${ }^{47}$ though they do not so far seem to have been effective. ${ }^{48}$ And it has begun to rein in outlandish theories of patent damages. ${ }^{49}$

By 2015, the tenor of the debate had changed. A growing number of commentators worried that the effect of patent reforms designed to curb abuses by patent trolls would be to weaken the patent system as a whole, and with it American competitiveness. Not surprisingly, patent trolls have complained long and loudly about various reforms they (rightly) perceived as

44 Alice Corp. Pty. Ltd. v. CLS Bank Int'l, 134 S.Ct. 2347 (2014); Mayo Collaborative Servs. v. Prometheus Labs, Inc., 132 S.Ct. 1289 (2012). For an early recognition of the "counterrevolution" on the issue of patentable subject matter, see Thomas Cotter, A Burkean Perspective on Patent Eligibility, Part II: Reflections on the (Counter) Revolution in Patent Law, 11 Minn. J. L., Sci. \& Tech. 365 (2010).

45 Festo Corp. v. Shoketsu Kinzoku Kogyo Kabushiki Inc., 535 U.S. 722 (2002). For data on the effects of this, see John R. Allison \& Mark A. Lemley, The (Unnoticed) Demise of the Doctrine of Equivalents, 59 Stan. L. Rev. 955 (2007). See also Lee Petherbridge, On the Decline of the Doctrine of Equivalents, 31 Cardozo L. Rev. 1371 (2010) (independently confirming this result).

46 In re Seagate Tech., LLC, 497 F.3d 1360 (Fed. Cir. 2007) (en banc). That result may be overturned in whole or in part in the Supreme Court this term, however. See Halo Elecs., Inc. v. Pulse Elecs., Inc., 2016 WL 280769 (U.S. argued Feb. 23, 2016).

47 See, e.g., In re Genentech, Inc., 566 F.3d 1338 (Fed. Cir. 2009) (one of several Federal Circuit cases ordering the Eastern District of Texas to transfer cases to another district).

48 Forty-four percent of all patent cases filed in the country in 2015 were filed in the Eastern District of Texas. www.lexmachina.com.

49 See, e.g, Ericsson, Inc. v. D-Link Sys., Inc., 773 F.3d 1201 (Fed. Cir. 2014); Uniloc USA, Inc. v. Microsoft Corp., 632 F.3d 1292 (Fed. Cir. 2011); Lucent Techs., Inc. v. Gateway, Inc., 580 F.3d 301 (Fed. Cir. 2009). 
aimed at their business model. ${ }^{50}$ But they have gained allies on a number of fronts. Gene Quinn of IP Watchdog, originally no fan of patent trolls, ${ }^{51}$ has changed his mind and now complains that patent reforms directed at trolls are destroying the patent system. ${ }^{52}$ Professors like Richard Epstein and Adam Mossoff argue that patent reform was an overreaction. ${ }^{53}$

Practicing lawyers are upset about the difficulty they have in obtaining and enforcing software patents after the Supreme Court's limits on patentable subject matter. ${ }^{54}$ Companies like Apple and Microsoft - long the target of patent trolls themselves ${ }^{55}$-- have nonetheless worried about the limits courts have placed on software patents. ${ }^{56}$ Even the former head of the PTO has expressed concern over the trends in the patent system. ${ }^{57}$

50 See, e.g., Peter Detkin, 5 Inconvenient Truths About Patent Reform, http://www.intellectualventures.com/insights/archives/5-inconvenient-truths-about-patent-reform/ (complaints about patent reform from the general counsel of Intellectual Ventures); Gene Quinn, In Defense of Innovators: An Exclusive Interview with Ray Niro, IP Watchdog, July 21, 2013, http://www.ipwatchdog.com/2013/07/21/in-defense-of-innovators-an-exclusive-interview-with-rayniro/id=43498/.

51 See, e.g., Gene Quinn, The Problem With Patent Trolls, IP Watchdog, July 28, 2011, http://www.ipwatchdog.com/2011/07/28/the-problem-with-patent-trolls/id=18345/ ("Recently several of my articles have been critical against patent trolls. This is not something new for me, I have been critical of patent trolls for quite some time.").

52 See, e.g., Gene Quinn \& Paul Morinville, Patent Reform riddled with intended, unintended, and unknown consequences, IP Watchdog, July 27, 2015, http://www.ipwatchdog.com/2015/07/27/patentreform-riddled-with-intended-unintended-and-unknown-consequences/id=60030/.

53 Epstein, supra note _, at __; Mossoff, supra note _, at _.

54 See, e.g., Robert R. Sachs, \#Alicestorm: When It Rains, It Pours . . , BilskiBlog, Jan. 22, 2016, http://www.bilskiblog.com/blog/2016/01/alicestorm-when-it-rains-it-pours.html.

55 Apple was a plaintiff in 33 patent cases between 2000 and February 24, 2016 and a defendant in 477 cases. Microsoft was a plaintiff in 38 patent cases and a defendant in 340 during the same period. www.lexmachina.com.

56 See, e.g., Julie Samuels, The biggest threat to patent reform: The Apple/IBM/Microsoft coalition, Venture Beat, April 6, 2014, http://venturebeat.com/2014/04/06/the-biggest-threat-to-patent-reforma-new-appleibmmicrosoft-coalition/.

57

Kappos, supra note _, at _. 
People in Congress seem to be listening to those concerns. A patent reform bill designed to do what the AIA did not - target patent troll litigation - looked like a shoo-in in 2014, but it ran aground in 2015 and appears dead for the foreseeable future. ${ }^{58}$ And if legislation does pass, it seems likely to undo one of the most significant patent-restrictive reforms of the last decade by weakening the IPR procedure. ${ }^{59}$

\section{Equilibrium and the Pendulum}

These changes seem to fit a larger pattern in the history of patent law. We have seen multiple swings between eras of strong and weak patent protection. Each seems to be a reaction to the perceived excesses of the era before. The expansive protection from the 1980s through the early 2000s was a reaction to the perception that patent law in the 1960s and 1970s was unduly weak. ${ }^{60}$ That period in turn followed a period of strong protection ushered in by the Patent Act of 1952, which was in turn a reaction to weak protection in the 1930 s and 1940s. And so on. ${ }^{61}$ Indeed, the swinging pendulum in patent law dates back as far as the late

58 See, e.g., Brett Norman \& Sarah Karlin, As Congres returns, patent reform hits the skids, Politico, Sept. 8, 2015, http://www.politico.com/tipsheets/prescription-pulse/2015/09/proprescriptionpulsesept8-karlin-norman-210101

59 See STRONG Patents Act, http://patentlyo.com/media/2015/03/STRONG-Patents-Act-of-2015.pdf (introduced by Senator Coons to make it harder to challenge patents in IPR proceedings, and now part of the proposed Patent Act).

60 See, e.g., Rochelle Cooper Dreyfuss, The Federal Circuit: A Case Study in Specialized Courts, 64 N.Y.U. L. Rev. 1 (1989).

61 See, e.g., Mark A. Lemley, A New Balance Between IP and Antitrust, 13 Sw. J. L. \& Trade Americas 237 (2007). 
$16^{\text {th }}$ century, when a period of perceived overprotection and laxity in granting patents was followed by the passage of the Statute of Monopolies in Parliament in $1623 .^{62}$

These may in fact be cycles of over- and underprotection. The relationship among patents, innovation, and economic growth is a complicated one we don't fully understand. It is quite possible that every generation of Congress, judges, and patent lawyers sees the imperfections of the decades before and overreacts to it. I have argued in the past that we should try to moderate these swings because both too much and too little patent protection is bad for the world. ${ }^{63}$ But for my purposes in this paper it doesn't matter. You can believe that we cycle between appropriate protection and radical underprotection, or between appropriate protection and radical overprotection. The point I want to make is that in the past thirty years we have seen the pendulum swing towards stronger protection and then, more recently, towards weaker protection. And in each case, thoughtful scholars and advocates worried that the current trend was bad for the world and needed to be moderated or reversed.

We might expect to see stronger patent protection associated with more applications, more grants, more lawsuits, and more business transactions, and the shift to weaker protection associated with the opposite. But that is not what happened. Remarkably, the fundamental

62 See, e.g., LeWIS EdMUnds, The LAW ANd PRACtice Of LetTers PATENT FOR InVENTIONS 7-8 (London, Stevens \& Sons 1890) (relating the case of Mompesson and Mitchell, who were stripped of their patents, fined, imprisoned, and "forced to ride through the streets of London on a horse with his face to the tail" for abusing the patent granted to them in the early part of the Seventeenth Century). Patent abuses of this sort led to the Statute of Monopolies, which forbad all patents except those based on invention, and limited the latter to a specific term of years. 21 Jac. 1 c.3 (1623). For discussion, see, e.g., Adam Mossoff, Rethinking the Development of Patents: An Intellectual History, 1550-1800, 52 Hastings L.J. 1255 (2001); Ramon A. Klitzke, Historical Background of the English Patent Law, 41 J. Pat. Ofc. Soc'y (1959); Thomas B. Nachbar, Monopoly, Mercantilism, and the Politics of Regulation, 91 Va. L. Rev. (2005).

63 Lemley, New Balance, supra note 
characteristics of the patent system seem remarkably unaffected by either the changes in substantive law or the changes in technology and legal procedure.

The graph of patent applications filed shows a more or less linear increase in applications over the past 15 years, a period during which the number of applications more than doubled. ${ }^{64}$ There is a slight leveling that corresponds to the Great Recession of 2008-09, but then the increase continues. The substantive changes that began to weaken patent protection starting around 2006 do not seem to have deterred people from filing patent applications.

64 Because many patent applicants file multiple applications, called continuations, based on the same parent application, these numbers overstate the number of unique applications filed in each year. See, e.g., Lemley \& Moore, supra note _. The number of true continuations has actually declined since 1999 because applicants can now file an alternative "Request for Continued Examination" that does not get counted as a new application, and many do so. 15.8\% of the applications filed between 1996 and 2005 used a true continuation. Michael Carley, Deepak Hegde, \& Alan Marco, What is the Probability of Receiving a US Patent? at 6 (2014), available at http://www.uspto.gov/ip/officechiefecon/OCE WP 2013-2.pdf. 


\section{Figure 3}

\section{U.S. Patent Statistics Chart}

\section{Calendar Years 1999 - 2014}

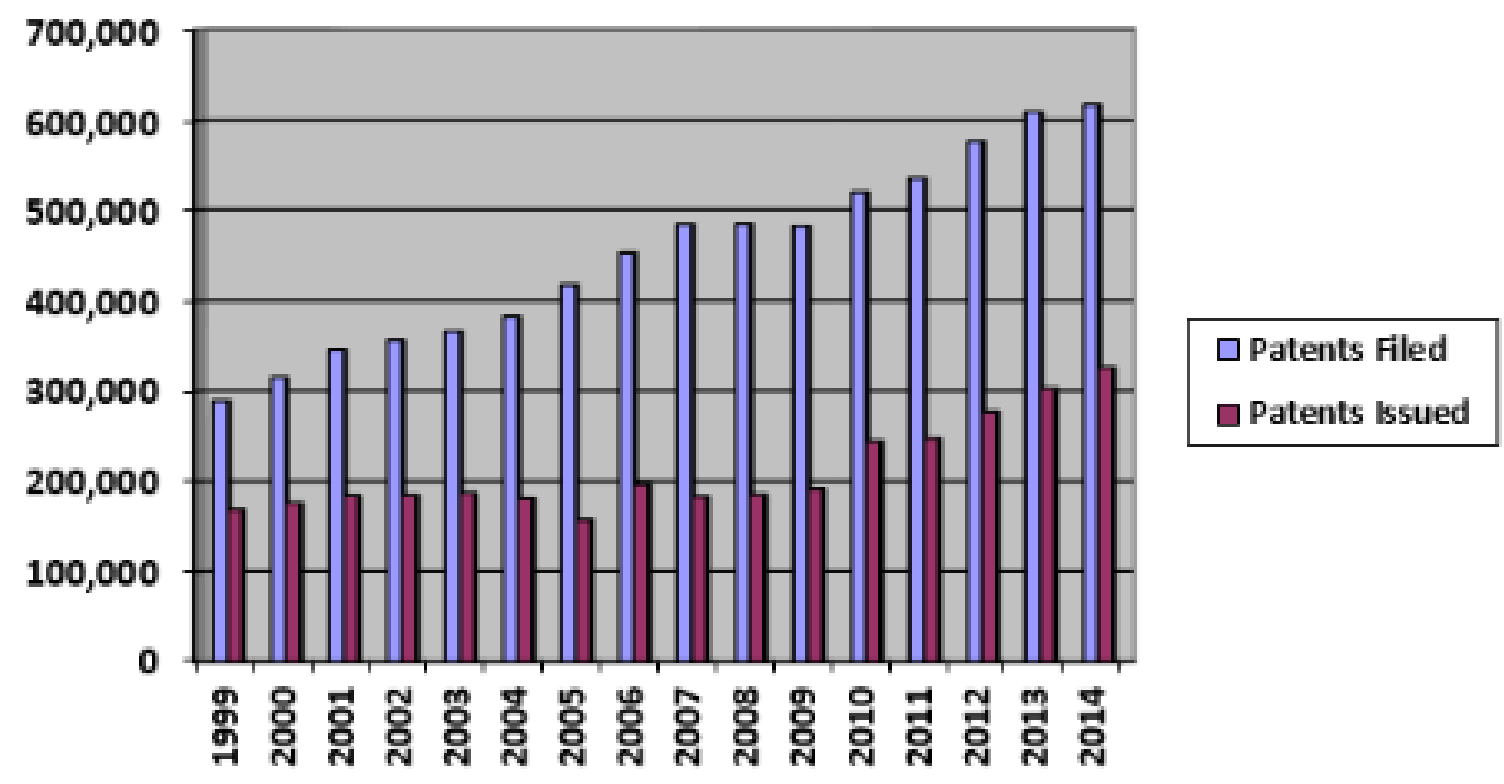

65 That process continues to this day. Despite challenges to software and biotechnology patents in particular, 2016 is on track to produce a record number of both patent applications and issued patents.

65 http://media.insidecounsel.com/insidecounsel/article/2015/06/03/060415snell1.png. 


\section{Figure 4}

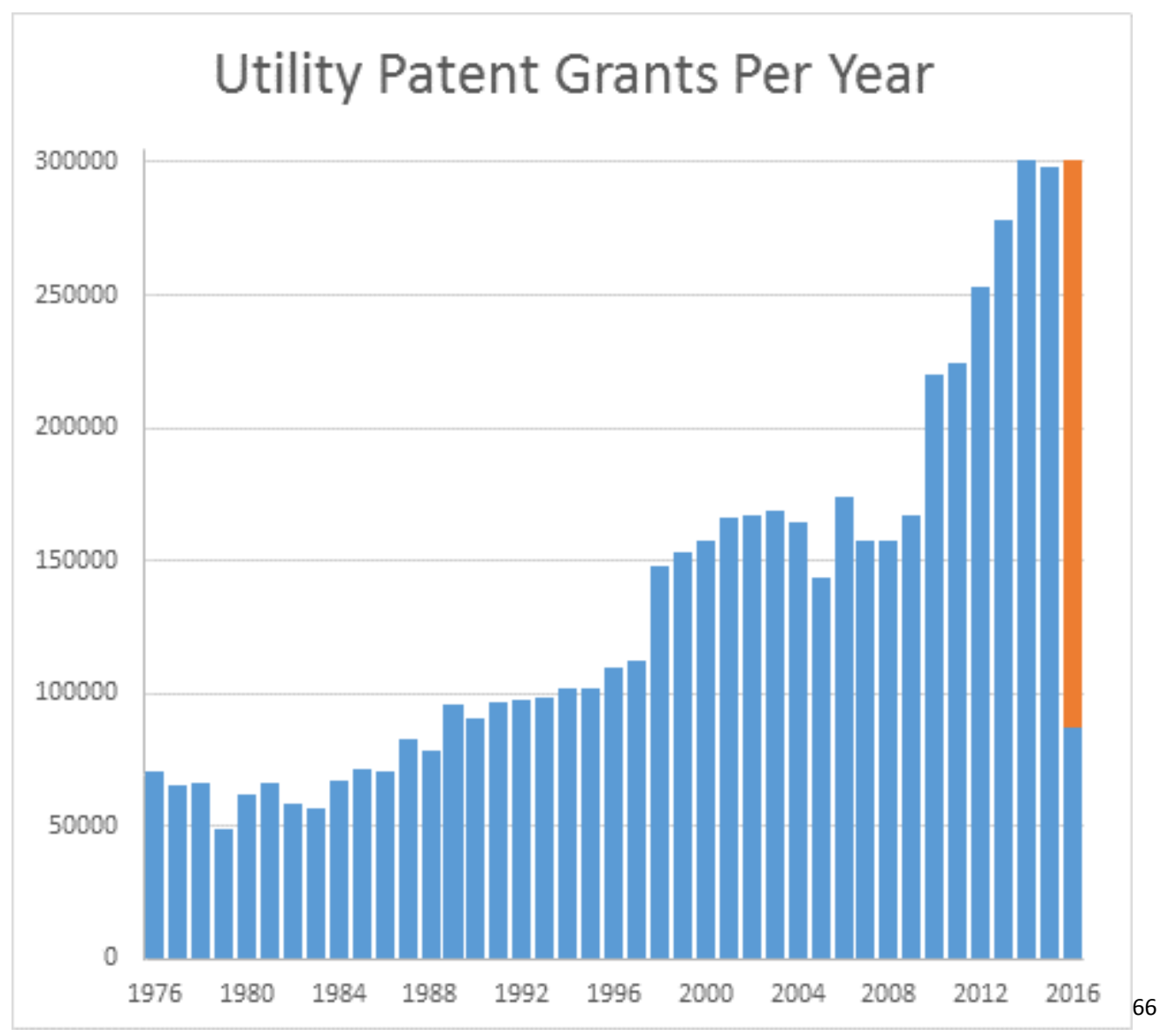

66 Dennis Crouch, Patent Grants 2016 Update, April 17, 2016, http://patentlyo.com/patent/2016/04/patent-grants-update.html 
Figure 5

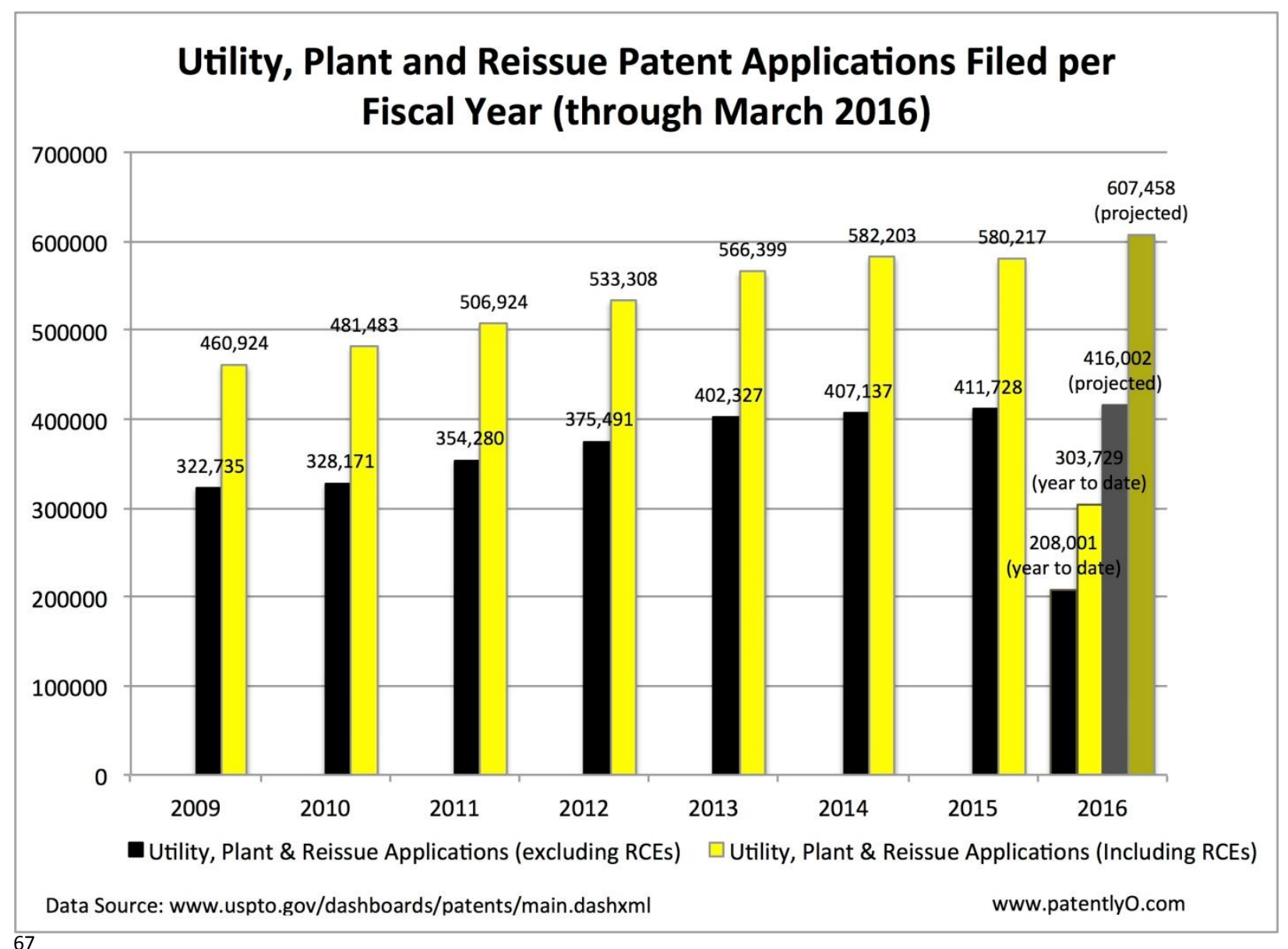

Nor does the graph of utility patent grants show any obvious relationship to the pendulum swings of the patent system. Unlike the number of applications, this shows more significant variation over time, though the overall number doubled in the last 15 years, as it did with applications. ${ }^{68}$ Whether or not we adjust for the 3-4 year average patent pendency, the swings in grant rate don't map to the changes in patent doctrine. Patent grants essentially leveled off

67 Jason Rantanen, Patent Applications and Grants Holding Steady for FY 2016, April 21, 2016, http://patentlyo.com/patent/2016/04/patent-applications-holding.html

68 Note that one cannot simply compare the numbers of applications and issued patents, both because of the delay between filing and issue and because of the presence of continuations. Two careful studies that sought to control for these issues both come to the conclusion that the patent grant rate is roughly $72 \%$. Carley et al., supra note , at 6; Lemley \& Sampat, supra note , at 
for a decade, from 2000 to 2010, and then increased dramatically after 2010. That means that the PTO was granting many more patents during the period in which patents were getting weaker (and theoretically harder to obtain) than during the height of the pro-patent swing.

Figure 4

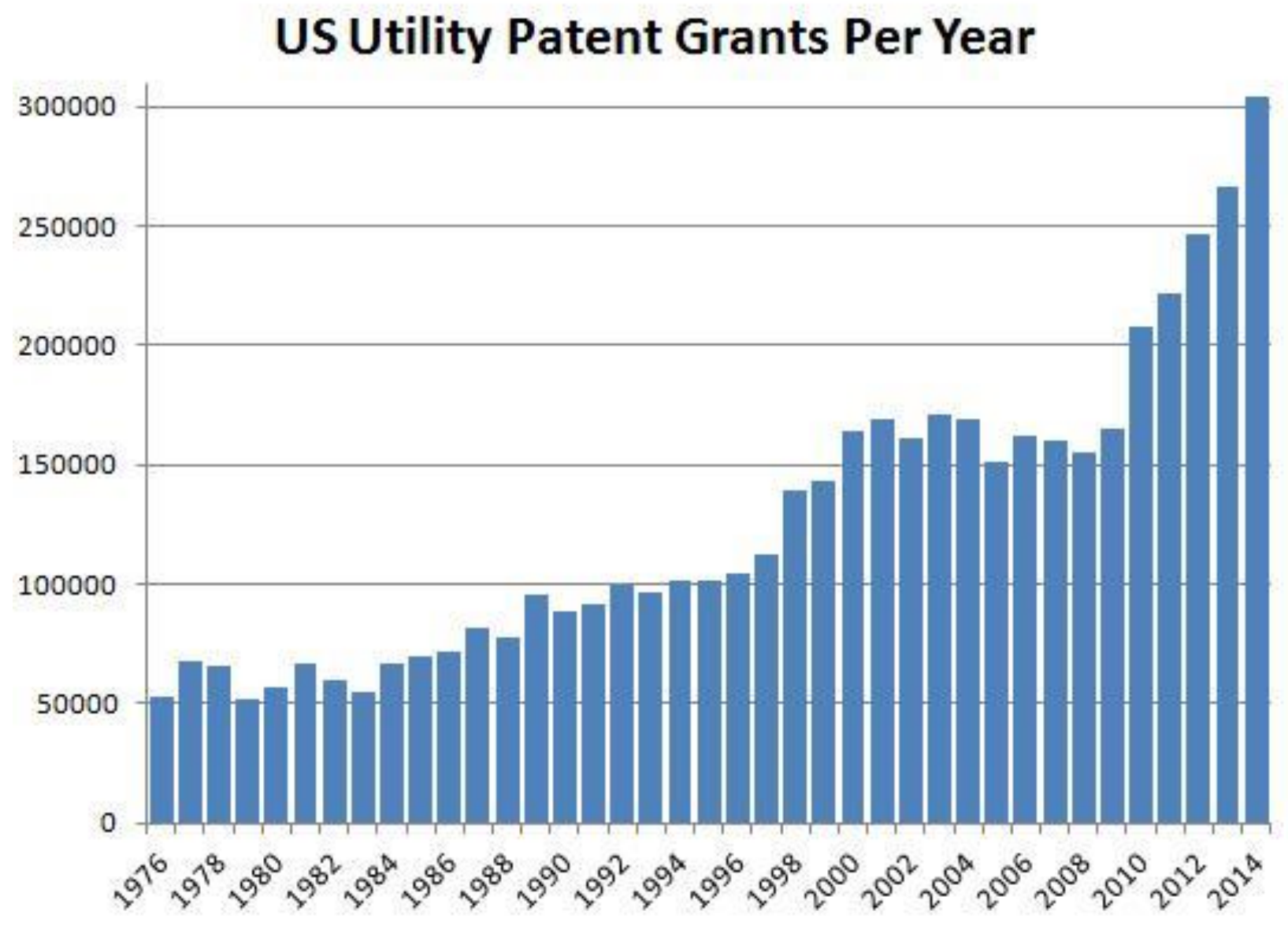

69

The changes are more likely a function of changes in PTO administration than bigger changes in patent law. The grant rate dropped under the leadership of Jon Dudas, the head of the PTO

69 http://patentlyo.com/media/2014/09/PatentsPerYear.jpg 
during much of the Bush administration, and then rose substantially when the Obama administration appointed Dave Kappos and then Michelle Lee. ${ }^{70}$

The number of lawsuits also doesn't seem to easily fit a pattern that ties to substantive changes in patent law.

Figure 5

Patent Cases Commenced, 1980 - 2012

6000

5000

4000

3000

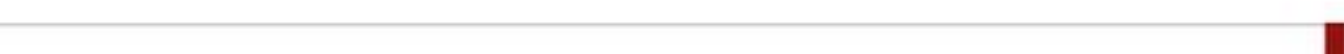

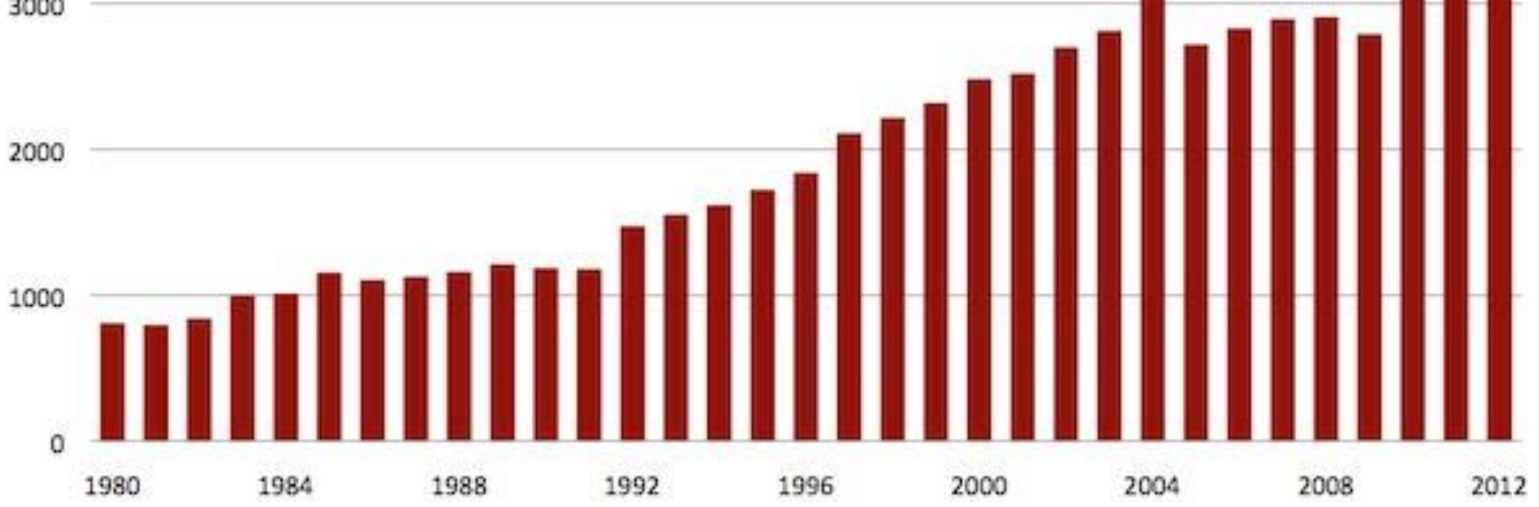

71

As Figure 4 shows, the number of lawsuits does in fact seem to increase steadily during the period of expansive patent protection, then level off in the last half of the 2000s. But the

70 For discussion of the role PTO administration can play in influencing patent grant rates, see Michael D. Frakes \& Melissa F. Wasserman, The Failed Promise of User Fees: Empirical Evidence From the U.S. Patent and Trademark Office, 11 J. Empirical L. Stud. 602 (2014).

71 http://www.ipwatchdog.com/images/patent-litigation-commenced-1980-2012.jpg 
number of lawsuits started to increase again in 2010, even as courts were cutting back on the scope of substantive patent doctrine.

Because the number of issued patents changed during this period, a more appropriate measure might be the percentage of patents in force that are litigated in any given year. Figure 5 shows that the number of suits per patent dipped in the 1980s and early 1990s, even as patent law was strengthening. The number of suits per patent increased in the 1990s, but then leveled off even before 2000 , despite the strength of patent protection in that period. It dropped in the late 2000s before picking up by 2011.

Figure 6

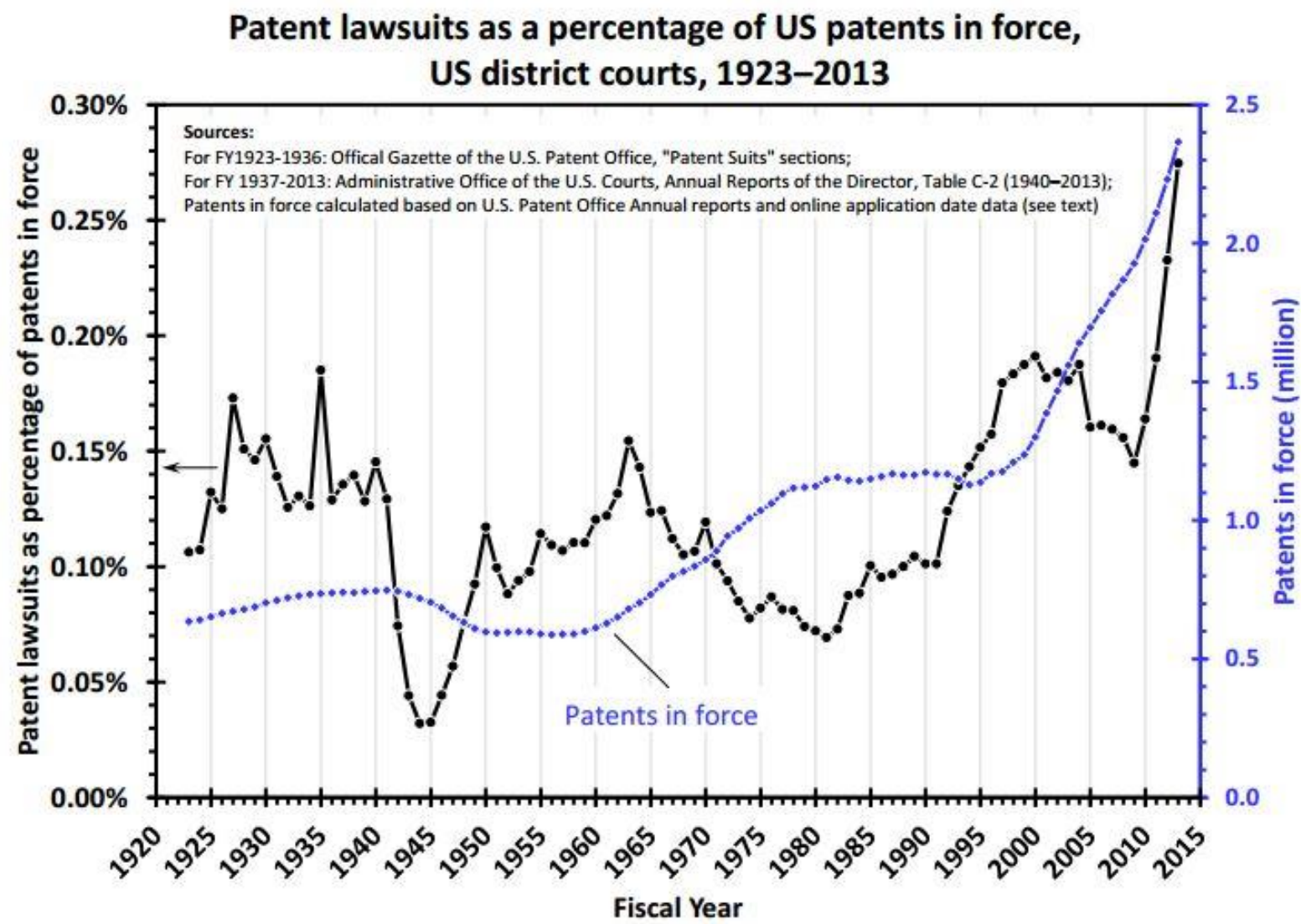

72

72 http://patentlyo.com/media/2014/11/PatentsInForce.jpg 
The law changed in the fall of 2011 in a way that required plaintiffs who sued multiple defendants on the same patent to do so in multiple suits. As a result, the sharp increase in the number of suits filed in 2012 and thereafter is an anomaly. The numbers reached a new, higher plateau after 2012.

\section{Figure 7}

\section{Patent Lawsuits by Year, 2009-2015}

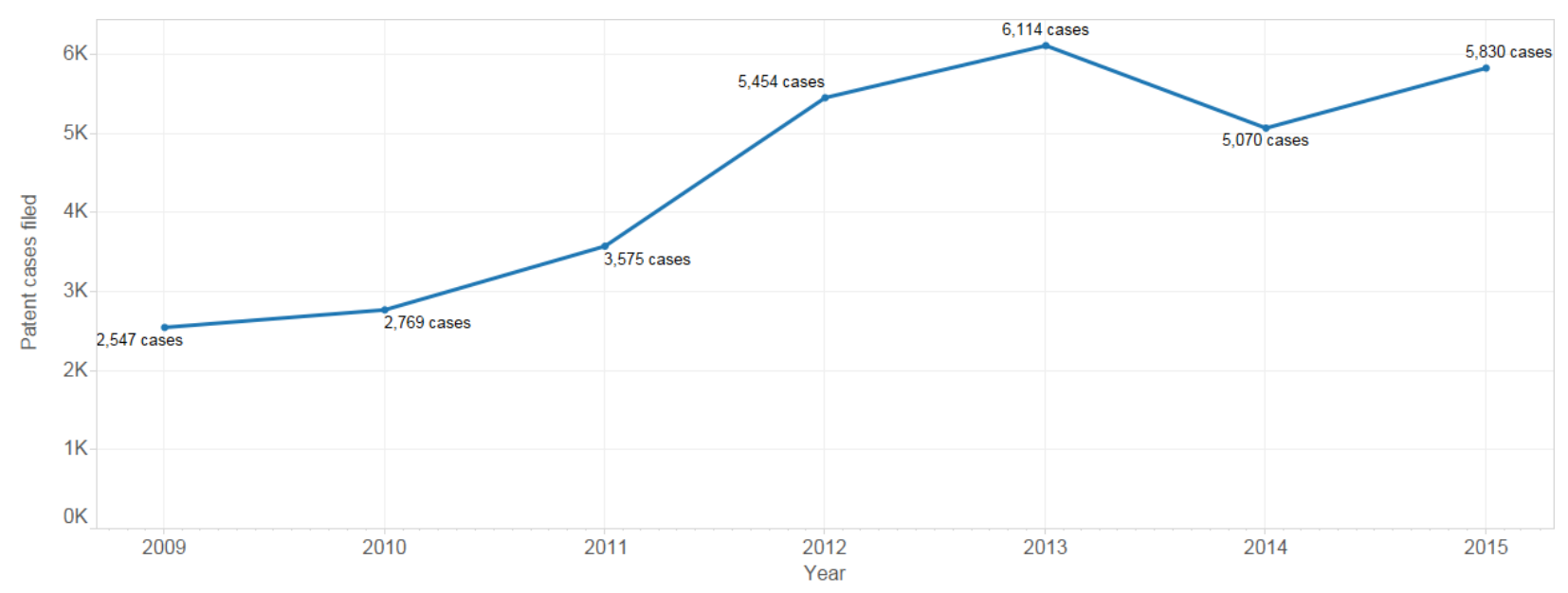

73

For that reason, a better measure of change may be the number of defendants sued.

Robin Feldman studied that issue and found a much less substantial increase in the number of

73 https://lexmachina.com/wp-content/uploads/2016/01/Fig-1a-By-year.png.

There is some evidence that patent lawsuits are falling in 2016. Lex Machina reports that there were only 1582 patent lawsuits filed through May 17, 2016, compared with over 2000 to the same date in each of the last two years. Whether that represents a longer-term trend remains to be seen. Lawsuits dropped in the last half of 2014 after the Alice decision, only to rebound in 2015 to near-record levels. And a rule change effective December 1, 2015 encouraged many plaintiffs to file suit at the end of November 2015, meaning that the slower litigation rate so far in 2016 could simply be the result of plaintiffs rushing to court with suits that would more naturally have been filed over the next several months. 
defendants sued from 2007 through 2012. The numbers certainly did not decline, however, even as courts were cutting back on patent protection.

\section{Figure 8}

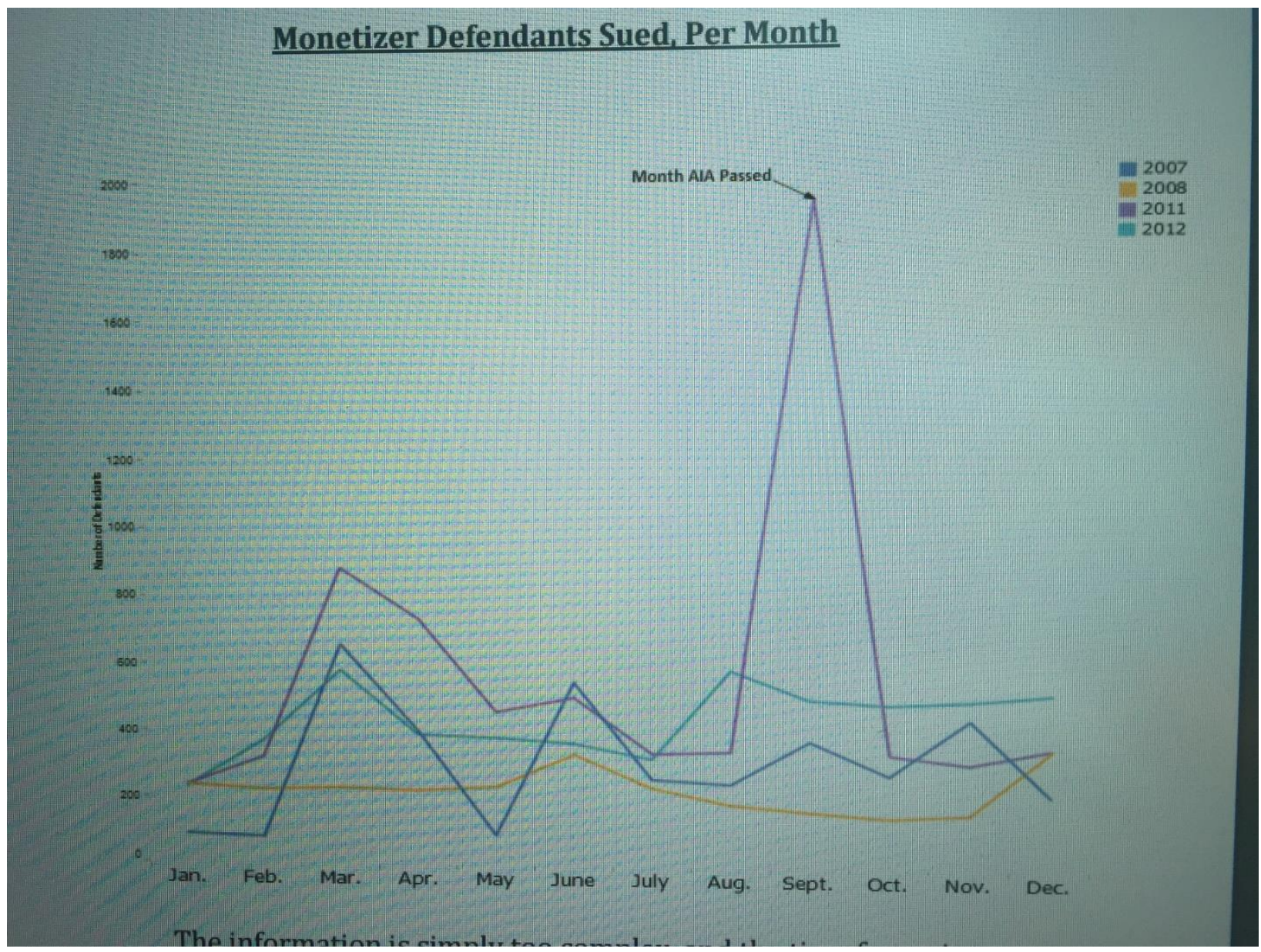

While there are arguments for and against using any of these measures of patent litigation, what is notable is that by none of these measures does patent litigation seem to track the changes in the strength of patent rights.

Nor is there an obvious relationship between patent strength and the robustness of patent markets. Most patent sales and licenses are confidential, so good data on patent

\footnotetext{
74 Feldman, Ewing, \& Jeruss, supra note
} , at 
markets is hard to come by. But we can get some sense by looking at the market for brokered patent sales. The size of the market has stayed roughly the same over the past five years or even grown modestly, even as various decisions weakened patent protection and might be thought to have reduced the value of many patents. ${ }^{75}$ There is even anecdotal evidence that the market is expanding. ${ }^{76}$ Indeed, some patent transaction intermediaries reported that 2015 was a record year for them. ${ }^{77}$

75 Because the chart shows the cumulative value of transactions, the easiest way to measure growth is to determine how long it takes to reach another $\$ 1$ billion in sales. That number starts out at five quarters in 2011-12, but drops to roughly three quarters by 2015.

76 Certified Patent Valuation Analyst declared in February 2016 that "patent valuations are set to surge." CPVA, Patent Valuations Are Set to Surge, email, February 19, 2016 (on file with author). 77 Louis Charbonneau data. 


\section{Figure 9}

\section{Brokered Patent Market}

Total Asking Prices (\$M) - Brokered and Private Market

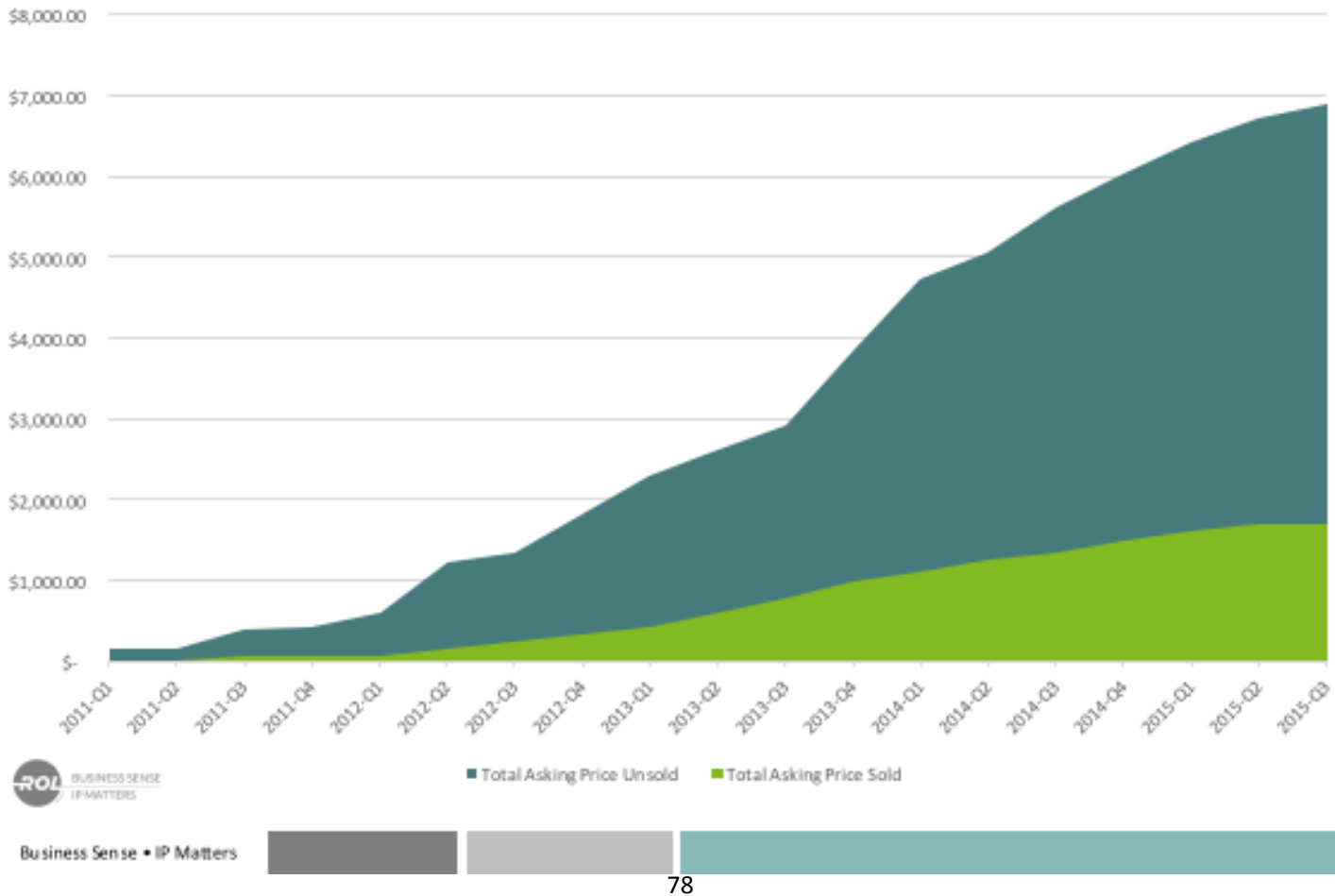

Finally, and perhaps most surprising, the outcome of patent litigation has also proved remarkably insensitive to substantive changes in patent law, at least since the creation of the Federal Circuit in 1982. Don Dunner's 1995 study of patent validity decisions found that of patents litigated to a final decision on validity between 1982 and $1994,58 \%$ were held valid. $^{79}$ In 1998 , Allison and Lemley found that $54 \%$ of cases litigated to decision on validity between

78 Kent Richardson, Erik Oliver, \& Michael Costa, The brokered patent market in 2015 - driving off a cliff or just a detour?, Intellectual Asset Mag., Jan./Feb. 2016, at 9, 10 Fig. 1.

79 Dunner, supra note _ , at _. That reflected a long-term increase over the immediate pre-Federal Circuit period, when the win rate on validity was $35 \%$. Koenig, supra note _, at _ 
1989 and 1996 were held valid. ${ }^{80}$ And in 2015, Allison, Lemley, and Schwartz found that 57\% of cases filed in 2008 and 2009 and litigated to decision on validity between 2009 and 2013 were held valid. ${ }^{81}$ And while it is too soon to know whether those numbers changed after the Supreme Court's Alice decision in 2014, which did lead to more invalidations of software and some biotechnology patents, recent evidence from administrative revocation proceedings at the Patent Trial and Appeal Board suggests that between 2012 and 2015 the invalidation rate was . . 42.3\%. ${ }^{82}$

We see a similar result with studies of overall patentee win rate. Because patentees must win both validity and infringement to win their case, patentee overall win rates are significantly lower than their win rates on individual issues like validity. ${ }^{83}$ In 2006, Paul Janicke and LiLan Ren found that patentees won $25 \%$ of all cases decided between 2002 and 2004. A decade later, Allison, Lemley, and Schwartz found that patentees won $26 \%$ of cases filed in 2008 and 2009 and litigated to decision on validity between 2009 and 2013.

Think about these numbers for a minute. Over the past two decades, even as we have seen dramatic changes in the substantive law, first in one direction and then another, the outcome of litigated cases has essentially remained unchanged. At least when it comes to court outcomes, accused infringers don't seem to have suffered from the expansion of patent

80 John R. Allison \& Mark A. Lemley, Empirical Evidence on the Validity of Litigated Patents, 26 AIPLA Q.J. 185 (1998).

81 John R. Allison, Mark A. Lemley, \& David L. Schwartz, Understanding the Realities of Modern Patent Litigation, 92 Tex. L. Rev. 1769 (2014).

82 Lex Machina Patent Trial and Appeal Board 2015 Report, https://lexmachina.com/media/press/2015report-on-ptab-litigation/ (January 21, 2016).

83 Mark A. Lemley, The Fractioning of Patent Law, in Intellectual Property and the Common Law 504 (Shyamkrishna Balganesh ed., Cambridge University Press 2013). 
law in the 1980s and 1990s, at least in court, and patentees in court similarly don't seem to have suffered from the substantive changes over the past decade that weakened patent rights. Indeed, if anything patentees do slightly better in today than they did when patents were at their strongest, though the differences are tiny.

Finally, one variable in the patent system remains unobservable - how much money is paid out in settlements. Because patent settlements are almost always confidential, there is no way to know whether changes in substantive law are reflected in differences in how much people pay to settle cases. ${ }^{84}$ We do know, however, that damage awards in the cases that do go to trial don't seem to map to swings in the substantive law of patents.

84 See, e.g., Mark A. Lemley \& Nathan Myhrvold, How to Make a Patent Market, 36 Hofstra L. Rev. 257 (2008) (lamenting this fact). 


\section{Figure 10}

\section{Cumulative District Court Patent Damage Awards}

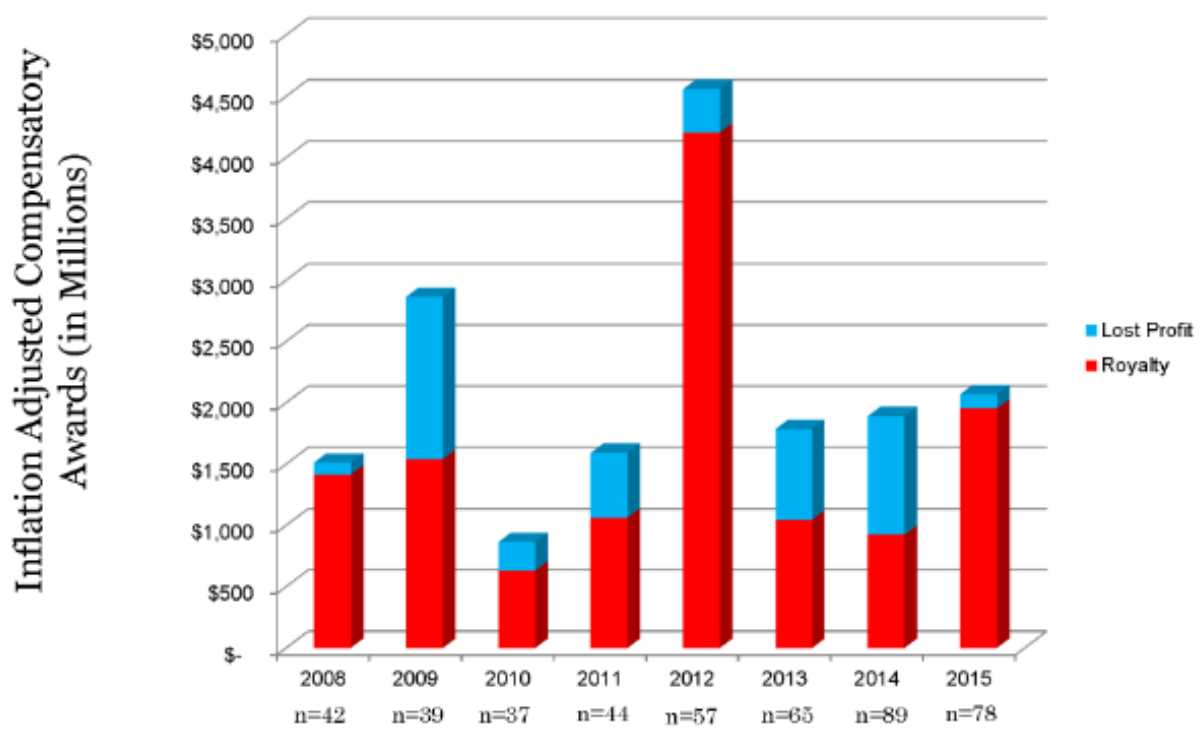

Settlements should logically be a function of what the patentee could expect to receive if it won the case, ${ }^{86}$ though settlements in bottom-feeder troll cases are a function of the cost of litigation. So, while there is no way to know if the price paid in settlements is declining, any decline is more likely to be attributable to changes in the cost of litigation than in the substantive outcomes of the cases that do go to judgment. Those substantive outcomes haven't changed much over the years.

85

https://media.licdn.com/mpr/mpr/shrinknp_800_800/AAEAAQAAAAAAAARJAAAAJDA5MjYyZWQ5LTRk Y2QtNDNmYS05Zjg5LWRjY2ZhZDU0ZGIwNg.png

86 Lemley \& Shapiro, supra note _, at _; Thomas Cotter, Patent Holdup, Patent Remedies, and Antitrust Responses, 34 J. Corp. L. 1151 (2009). 
None of this means that the practice of patent litigation is unchanged. Indeed, there is anecdotal evidence of downturns at patent litigation firms. But that doesn't seem to result from either the filing of fewer lawsuits or the fact that patentees are less likely to win those lawsuits. Rather, the fact that litigation is being resolved more cheaply, often on a motion to dismiss, or stayed pending a cheaper IPR proceeding means that patent litigants are spending less money on lawyers. ${ }^{87}$ That's not great if you're a patent litigator, but it's probably good for everyone else in the system.

\section{The Sound and Fury of Patent Reform?}

The evidence presented in Part III presents a real puzzle. Why do the very real changes in the Patent and Trademark Office, the process of litigation, and the substance of legal rules seem to have no effect on how many people file patent applications, how many patents are issued, how many patents are licensed, how many suits are filed, or who wins those suits? Why is it that, as John Barton found back in 2000, growth in the number of patent lawyers is unrelated to and far outpacing growth in R\&D expenditures ${ }^{88}$ In this section, I consider some possible explanations.

\section{A. Selection Effects}

87 See, e.g., David Lat, Is Patent Litigation Dead? What Gives?, Above the Law, Nov. 11, 2015, http://abovethelaw.com/2015/11/is-patent-litigation-dead-what-gives/ (noting the slowdown at patent litigation firms and attributing it to early resolution of cases under Alice, but noting that patent litigation will continue).

88 John Barton, Reforming the Patent System, 287 Sci. 1933 (2000). To be fair, it is far from clear which way causation might run in that relationship. 
One possible explanation for some of these results is case selection. There seems little question that the legal rules and various other factors affect who files suit and who among that group takes their cases to trial or judgment. ${ }^{89}$ An extreme form of the selection effects story is the Priest-Klein hypothesis, which proposes that propensity to litigate is based not on the merits themselves, but on uncertainty about how those merits will be resolved. Priest and Klein suggest that parties will settle the easy cases (both the very good ones and the very bad ones), leaving only the toss-ups to go to court and driving win rates across the board to $50 \%{ }^{90}$ If that were true, it might explain why outcomes of the cases that do go to judgment seem largely unchanged even as the strength of patent rights changes significantly.

But there are reasons to question how much weight we can put on the Priest-Klein hypothesis. Others have criticized the relevance of the strong Priest-Klein theory to patent litigation. ${ }^{91}$ And Steven Shavell has argued that Priest and Klein are wrong as a general matter of theory. ${ }^{92}$ Further, the empirical evidence doesn't seem to support the strong version of the hypothesis in patent litigation. There is some evidence that there is not very much systematic variation in who files suits that settle compared to who files suits that don't. ${ }^{93}$ There are

89 For a detailed discussion of selection effects that may affect which patent cases settle and which go to judgment, see John R. Allison et al., How Often Do Non-Practicing Entities Win Patent Cases? (working paper 2016).

90 George L. Priest and Benjamin Klein, The Selection of Disputes for Litigation, $13 \mathrm{~J}$ Legal Stud 1, 16-17 (1984).

91 See, for example, Jason Rantanen, Why Priest-Klein Cannot Apply to Individual Issues in Patent Cases *3-8 (University of lowa Legal Studies Research Paper No 12-15, Aug 2012), archived at http://perma.cc/X994-NSRJ; David L. Schwartz, Pre-Markman Reversal Rates, 43 Loyola LA L Rev 1073, 1101-07 (2010).

92 Steven Shavell, Any Frequency of Plaintiff Victory at Trial Is Possible, 25 J. Legal Stud. 493 (1996).

93 Allison et al., How Often NPEs Win, supra note _, at _ (conducting a robustness check to try to estimate selection effects and finding that they did not explain differences in who won patent cases). 
systematic variations from $50 \%$ in win rates overall ${ }^{94}$ and in win rates measured by technology or the nature of the plaintiff. ${ }^{95}$ While some of that could be explained by the nature of patent litigation or asymmetric repeat players (who might care about establishing a litigation reputation), the evidence also suggests that win rates have moved over time before the period I study in ways Priest-Klein cannot explain. ${ }^{96}$

I certainly don't mean to suggest that there are no selection effects that affect which cases settle; surely there are. And they may go part way toward explaining the resilience of the patent system. But there is little reason to think that the strong form of the Priest-Klein hypothesis is accurate. So the fact that litigation outcomes don't change over the past thirty years remains an interesting fact that requires some explanation.

The Priest-Klein hypothesis tries to explain what subset of lawsuits settle and which ones go to trial. But selection effects may also influence whether or not patentees file suit at all, and therefore how many suits are filed. The first question is what happens to patents that are not enforced in court. Allison et al find that litigated patents tend to be valuable patents. ${ }^{97} \mathrm{~A}$ tougher question is whether there are "super-valuable" patents that are so obviously valid that everyone agrees to license them without litigation. ${ }^{98}$ If the most valuable patents tend to be

\footnotetext{
94 See supra notes ___ a and accompanying text (showing that the overall patentee win rate hovers around 25\%).

95 John R. Allison et al., Our Divided Patent System, 82 U. Chi. L. Rev. 1073 (2015); Allison et al., How Often Do NPEs Win?, supra note _, at _.

96 For instance, the patent validity rate was only $35 \%$ in the 1970 s, Koenig, supra note _, at _, and rose to roughly $55 \%$ in the 1980 s after the Federal Circuit was created. Dunner, supra note _, at _. It has stayed there ever since. Allison \& Lemley, Empirical Evidence, supra note _, at _; Allison et al., Understanding the Realities, supra note _, at _.

97 John R. Allison et al., Valuable Patents, 92 Geo. L.J. 435 (2004).

98 Id. at__ (discussing this issue).
} 
enforced in court, at least sometimes, one would expect the number of enforced patents, and hence the number of lawsuits, to increase as patent rights gets stronger, since marginal patents become worth enforcing. But if it is only the upper middle class patents - valuable but not super-valuable - that are being enforced, the expected effects of strengthening or weakening patent rights become more complicated. Weakening patent rights could conceivably increase the number of patent suits in this situation, as super-patents that would have been licensed without a fight get pushed into litigation. The result might or might not be an increase in the total number of suits; more likely it would simply shift which patents are litigated because they are at the margins of validity and infringement. But if we are simply shifting which patents are enforced, we may not see the effects of a change in the strength of a patent regime reflected in an increase or decrease in the total number of suits. Recent work by Andrew Torrance supports the claim that litigated patents are the most valuable patents, meaning this may not be as much of a worry. ${ }^{99}$

A second potentially confounding effect is the rise of patent trolls. Non-practicing patent plaintiffs rose from virtually none in the 1980s to well more than half of all lawsuits filed by 2015. The rise of patent troll lawsuits should have an effect on the total number of patent suits filed. If troll suits and practicing entity suits are independent of each other, an apples-to-apples comparison of patent lawsuits should require us to eliminate patent troll lawsuits and focus only on the year over year change in practicing entity suits. Doing so flattens the growth of

99 Andrew W. Torrance \& Jevin D. West, Are Litigated Patents More Important? (working paper 2016) (finding that litigated patents are more than five times as important on a weighted citation scale than the average patent). 
practicing entity suits considerably. ${ }^{100}$ Indeed, focusing only on entity classes 8 and 12 , corresponding to practicing entities, makes clear that the number of practicing entity suits remained roughly flat from 2000 to 2013 .

Figure 11

\section{Time Trends Near AIA}

\begin{tabular}{|c|c|c|c|c|c|c|c|c|c|}
\hline Code: & 1 & 5 & $\begin{array}{l}\text { 1or5 } \\
\text { only }\end{array}$ & 8 & $\begin{array}{c}8 \text { or } 12 \\
\text { only }\end{array}$ & 9 & 9 only & $\begin{array}{c}\text { Total } \\
\text { Coded }\end{array}$ & $\begin{array}{l}\text { Total } \\
\text { Filed }\end{array}$ \\
\hline 2000 & $\begin{array}{c}70 \\
(3 \%)\end{array}$ & $\begin{array}{c}155 \\
(7 \%)\end{array}$ & $\begin{array}{c}185 \\
(8 \%)\end{array}$ & $\begin{array}{c}1795 \\
(78 \%)\end{array}$ & $\begin{array}{c}1695 \\
(74 \%)\end{array}$ & $\begin{array}{c}365 \\
(16 \%)\end{array}$ & $\begin{array}{c}225 \\
(10 \%)\end{array}$ & $459^{\circ}$ & 2296 \\
\hline 2010 & $\begin{array}{c}330 \\
(12 \%)\end{array}$ & $\begin{array}{c}225 \\
(8 \%)\end{array}$ & $\begin{array}{c}559 \\
(21 \%)\end{array}$ & $\begin{array}{c}1865 \\
(69 \%)\end{array}$ & $\begin{array}{c}1745 \\
(64 \%)\end{array}$ & $\begin{array}{c}305 \\
(11 \%)\end{array}$ & $\begin{array}{c}190 \\
(7 \%)\end{array}$ & $543^{\circ}$ & 2716 \\
\hline 2011 & $\begin{array}{c}784 \\
(23 \%)\end{array}$ & $\begin{array}{c}532 \\
(16 \%)\end{array}$ & $\begin{array}{c}1235 \\
(37 \%)\end{array}$ & $\begin{array}{c}1848 \\
(55 \%)\end{array}$ & $\begin{array}{c}1708 \\
(51 \%)\end{array}$ & $\begin{array}{c}253 \\
(8 \%)\end{array}$ & $\begin{array}{c}162 \\
(5 \%)\end{array}$ & 3357 & 3533 \\
\hline 2012 & $\begin{array}{c}2018 \\
(37 \%)\end{array}$ & $\begin{array}{c}921 \\
(17 \%)\end{array}$ & $\begin{array}{c}2792 \\
(52 \%)\end{array}$ & $\begin{array}{c}2134 \\
(40 \%)\end{array}$ & $\begin{array}{c}2004 \\
(37 \%)\end{array}$ & $\begin{array}{c}276 \\
(5 \%)\end{array}$ & $\begin{array}{c}187 \\
(3 \%)\end{array}$ & 5392 & 5420 \\
\hline $2013^{*}$ & $\begin{array}{c}1857 \\
(40 \%)\end{array}$ & $\begin{array}{c}645 \\
(14 \%)\end{array}$ & $\begin{array}{r}2411 \\
(52 \%)\end{array}$ & $\begin{array}{c}1749 \\
(38 \%)\end{array}$ & $\begin{array}{c}1607 \\
(35 \%)\end{array}$ & $\begin{array}{c}285 \\
(6 \%)\end{array}$ & $\begin{array}{c}204 \\
(4 \%)\end{array}$ & $4605^{\circ}$ & $4638^{\circ}$ \\
\hline
\end{tabular}

It may be, however, that there is some relationship between the number of troll suits and the number of practicing entity suits. Practicing entities are increasingly spinning their patents off to NPEs who then assert the patents against competitors of the original owner, a practice known as privateering. ${ }^{102}$ The rise of trolls may therefore substitute for some practicing entity

100 See Shawn Miller, Second Look at the Stanford Litigated Patent Owner Dataset (working paper 2016).

101 Id. The numbers in the " 8 only" category exceed those for "8 plus 12 " because the latter category includes patent plaintiffs who were also classed in some other category, while the " 8 only" column includes only patent plaintiffs who were only listed as practicing entities.

102 Thomas L. Ewing, Indirect Exploitation of Intellectual Property Rights by Corporations and Investors: IP Privateering and Modern Letters of Marque \& Reprisal, 4 Hastings Sci. \& Tech. L.J. _ (2012); Robin 
suits that would otherwise be filed. While that may be a partial explanation, however, it is unlikely to account for anything like the majority of the $4000+$ troll suits filed every year.

Second, there may be some sense in which the rise of patent trolls drives out practicing entities. A large percentage of patent troll suits are not concerned with the merits, but are efforts to collect money based on the uncertainty and cost of litigation. ${ }^{103}$ And the vast majority of patent lawsuits are not filed against those accused of copying, but against defendants who themselves independently invented the technology.$^{104}$ The result may be a "market for lemons" effect ${ }^{105}$ in which the prevalence of demands by patent trolls seeking to extort nuisance-value settlements makes it less likely that potential licensees will respond favorably to any license demand. Technology companies confronted with multiple demands for money, many or most of which are frivolous and virtually none of which actually promise any real new technology, ${ }^{106}$ have a tendency to put their heads down and ignore all patents unless forced to confront them by lawsuit. ${ }^{107}$ This effect may drive more patents that would have Feldman \& Thomas Ewing, The Giants Among Us, 2012 Stan. Tech. L. Rev. 1 (2012) (documenting this phenomenon and coining the term "patent privateers" to describe it); Mark A. Lemley \& A. Douglas Melamed, Missing the Forest for the Trolls, 113 Colum. L. Rev. 2117 (2013) (discussing the prevalence of and problems with privateering).

103 Lemley \& Melamed, supra note _, at _.

104 Christopher A. Cotropia \& Mark A. Lemley, Copying in Patent Law, 87 N.C. L. Rev. 1421 (2009).

105 See George A. Akerlof, The Market for "Lemons": Quality Uncertainty and the Market Mechanism, 84 Q.J. Econ. 488 (1970). A market for lemons happens when customers cannot observe the quality of products, and so are unwilling to pay extra for putatively high-quality goods. This drives high-quality sellers out of the market, reducing the overall quality of the goods. This in turn reduces consumer willingness to pay, driving even the medium-quality goods out as well, until only the cheapest goods are worth manufacturing.

106 Robin C. Feldman \& Mark A. Lemley, Do Patent Licensing Demands Mean Innovation?, 101 lowa L. Rev. 137 (2015).

107 Mark A. Lemley, lgnoring Patents, 2008 Mich. St. L. Rev. 19. 
been licensed into litigation because litigation becomes the only way to get the attention of a licensee and prompt a deal.

A final form of selection effect may be at work: inventors as a class may be acting in various ways to modulate the level of protection they receive. John Golden has noted the complex nature of "innovation dynamics," which he analogizes to fluid mechanics. ${ }^{108}$ Changes that move patent law in one direction can produce complex feedback effects that return the system to equilibrium. Jonathan Barnett has argued that inventors as a group can privately modulate the appropriate level of IP protection by lobbying, reducing enforcement, or transacting to reduce overbroad IP rights. 109 The rise in the strength of patent protection, for instance, was accompanied by growth in private mechanisms like patent pools and standardsetting organization IP rules designed to weaken that protection. ${ }^{110}$ A push for patent reform, then, might be seen as the (political) market correcting its own imbalance, leading to a greater equilibrium. Whether that political market is efficient is another matter; balance depends critically on those holding the IP rights and the bargaining power having incentives to get the system right, not simply incentives to engage in greater rent-seeking. ${ }^{111}$

108 John M. Golden, Innovation Dynamics, Patents, and Dynamic-Elasticity Tests for the Promotion of Progress, 24 Harv. J. L. \& Tech. 47 (2010).

109 Jonathan M. Barnett, Property as Process: How Innovation Markets Select Innovation Regimes, 119 Yale L.J. 389 (2009). As Rebecca Eisenberg notes, however, forbearance from enforcement is a troubling thing to rely on, because patent owners who don't enforce their patents may ultimately sell those patents to trolls who will. Rebecca S. Eisenberg, Patent Costs and Unlicensed Use of Patented Inventions, 78 U. Chi. L. Rev. 53 (2011).

110 See, e.g., Mark A. Lemley, Intellectual Property Rights and Standard-Setting Organizations, 90 Cal. L. Rev. 1889 (2002) (identifying standard-setting organizations as an example of that phenomenon); Barnett, supra note _..

111 Some have argued that the ability to contract around strong property rules is a reason we shouldn't worry about overprotection. Robert P. Merges, Contracting Into Liability Rules: Intellectual Property Rights and Collective Rights Organizations, 84 Cal. L. Rev. 1293 (1996). As I have shown elsewhere, 
There is no question that there are complex and often cross-cutting unobservable effects that factor into what patent cases get filed and what filed patent cases make it to judgment. That said, I do not think selection effects can fully explain the lack of relationship between changes in patent law and litigation data that we saw in Part III. None of these stories offers a prediction that fully explains the litigation data. Indeed, many of the selection effects point in different directions. Further, even insofar as they affect the litigation data, they don't seem to have any obvious effect on the rates of patent applications, on patent issuance, or on patent markets. More sophisticated theories like Golden's can help explain long-term exponential or power-law growth in patenting, ${ }^{112}$ but cannot explain systematic deviations from those directional measures. ${ }^{113}$ Selection effects undoubtedly affect the litigation data we see, but they don't seem to explain away the puzzling insensitivity of fundamental patent metrics to changes in the law.

\section{B. Patents and the Broader Economy}

The resilience of patent system data may have more to do with general macroeconomic trends than with changes in the patent system. Patenting may be related to broader trends in economic growth. Economic growth is driven by productivity, and productivity is frequently driven by innovation, so it may make sense that that an increase in invention (and therefore an

however, parties can and do contract for more as well as less protection. Mark A. Lemley, Contracting Around Liability Rules, 100 Cal. L. Rev. 463 (2012); see also Michael J. Burstein, Exchanging Information Without Intellectual Property, 91 Tex. L. Rev. 227 (2012) (giving other examples).

112 Golden, supra note _, at 72-76.

113 Further, Golden's theory is at base consistent, not with selection effects, but with the idea that the merits don't matter as much as we think they do. See infra. 
increase in patenting) leads to an increase in economic growth. ${ }^{114}$ Others have suggested that patent litigation metrics may be countercyclical: patent owners don't file lawsuits or seek licensing revenue when the size of the pie is growing, but when growth lags and they need additional sources of revenue. ${ }^{115}$

Here, too, however, the relationships are likely a lot more complex. Because it takes time between invention and patent filing, and years longer between filing and issuance, we would expect some lag in any effect. In any event, the relationship between patents, industry, and innovation is a complex one. ${ }^{116}$ The relationship between innovation and productivity may also be problematic. ${ }^{117}$ So patenting may sometimes drive growth, but it may also interfere with it in some circumstances. ${ }^{118}$ Further, there is some reason to think that companies are more likely to spend the money on patents when they are doing well, so there may be a causal relationship running in the other direction between growth and patenting. ${ }^{119}$ And a recent study suggests that patent litigation is neither entirely cyclical nor entirely countercyclical. ${ }^{120}$

114 See, e.g., Lance Bachmeier et al., The Volume of Federal Litigation and the Macroeconomy, 24 Int'I Rev. L. \& Econ. 191 (2003); Golden, supra note _, at _.

115 See id. (noting this argument).

116 See, e.g., Dan L. Burk \& Mark A. Lemley, The Patent Crisis and How the Courts Can Solve It ch. 3-4 (2009) (noting the complex and industry-specific nature of the relationship between patents and innovation).

117 See, e.g., Bronwyn H. Hall, Innovation and Productivity, https://eml.berkeley.edu/ bhhall/papers/BHH11 Innovation Productivity NEPR.pdf.

118 See Bessen \& Meurer, supra note _.

119 For discussion of this relationship, see Ronald J. Mann, Do Patents Facilitate Financing in the Software Industry? 83 Tex. L. Rev. 961 (2005); John R. Allison, Abe Dunn, \& Ronald J. Mann, Software Patents, Incumbents, and Entry, 85 Tex. L. Rev. 1579 (2007).

120 Alan C. Marco, Shawn P. Miller, \& Ted M. Sichelman, Do Economic Downturns Dampen Patent Litigation?, 12 J. Empirical L. Stud. 481 (2015) (finding a complicated relationship that changes over time between economic downturns and patent litigation rates). Specifically, Marco et al interpret their data as finding that decreases in GDP are correlated with increases in patent litigation, suggesting that 
In any event, there doesn't seem to be any obvious unidirectional relationship between patenting and growth. Figure 8 shows the growth rate in patenting since 1960. Between 1960 and 1980 , patenting was roughly flat. Starting in the early 1980 s it began to rise at an annualized rate of about 4.4\%. By contrast, Figure 9 shows that inflation-adjusted GDP growth since 1960 runs at an annualized 3.4\%, at least until the 2007 recession, when it drops to $2.3 \%$ per year. The increase in patenting doesn't seem to have any effect on economic growth. Nor does economic growth seem to explain the increase in patenting.

Figure 12

US Patent Grants per Year

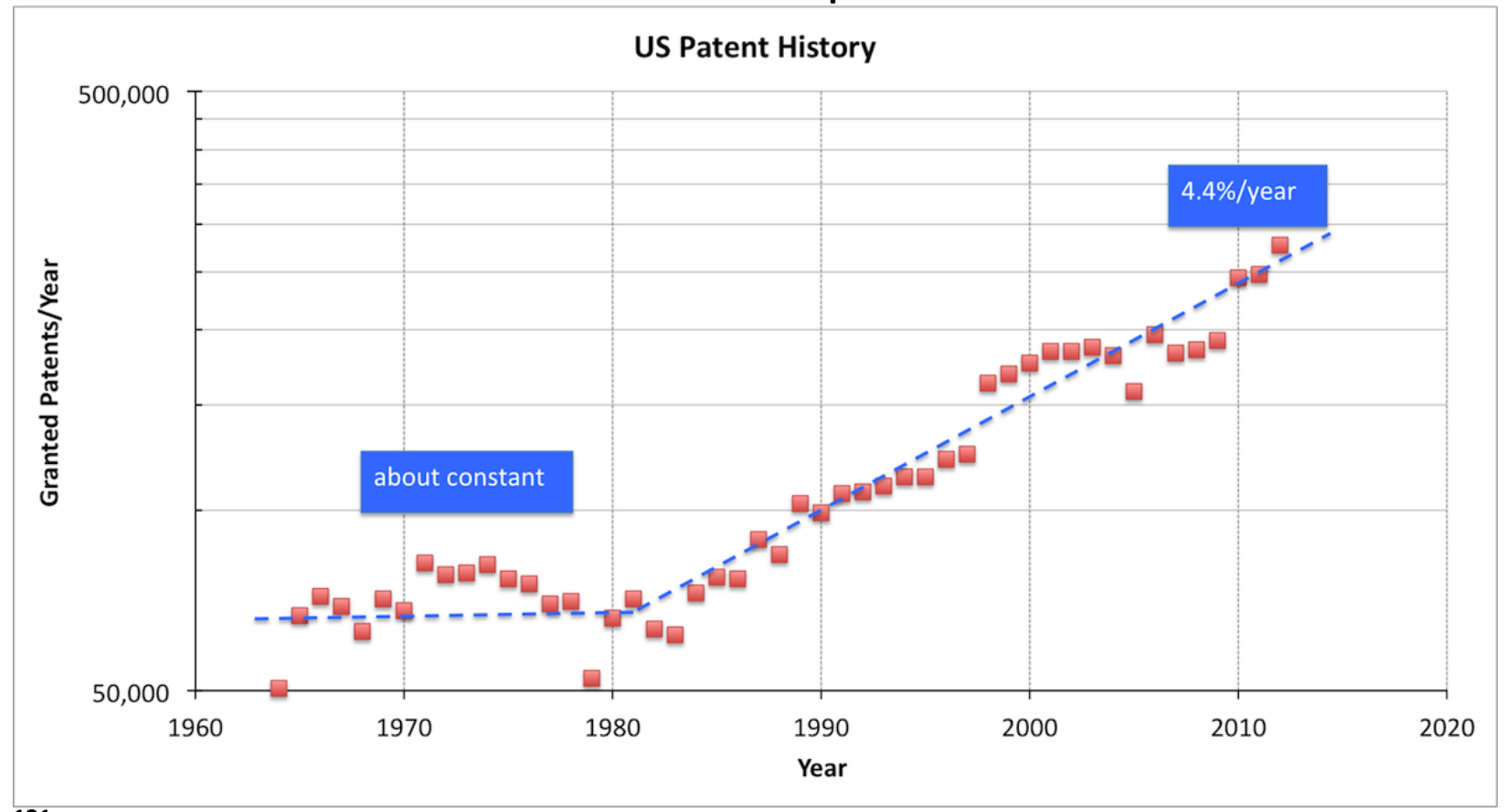

121

litigation is countercyclical, but only once one teases out the role of changes in interest rates. They find that higher interest rates are correlated with decreases in patent litigation. Id.

121 http://www.againstmonopoly.org/index.php?limit=\&chunk=0\&topic=IP\%20and\%20Economics 
Figure 13

\section{Economic Growth by Year}

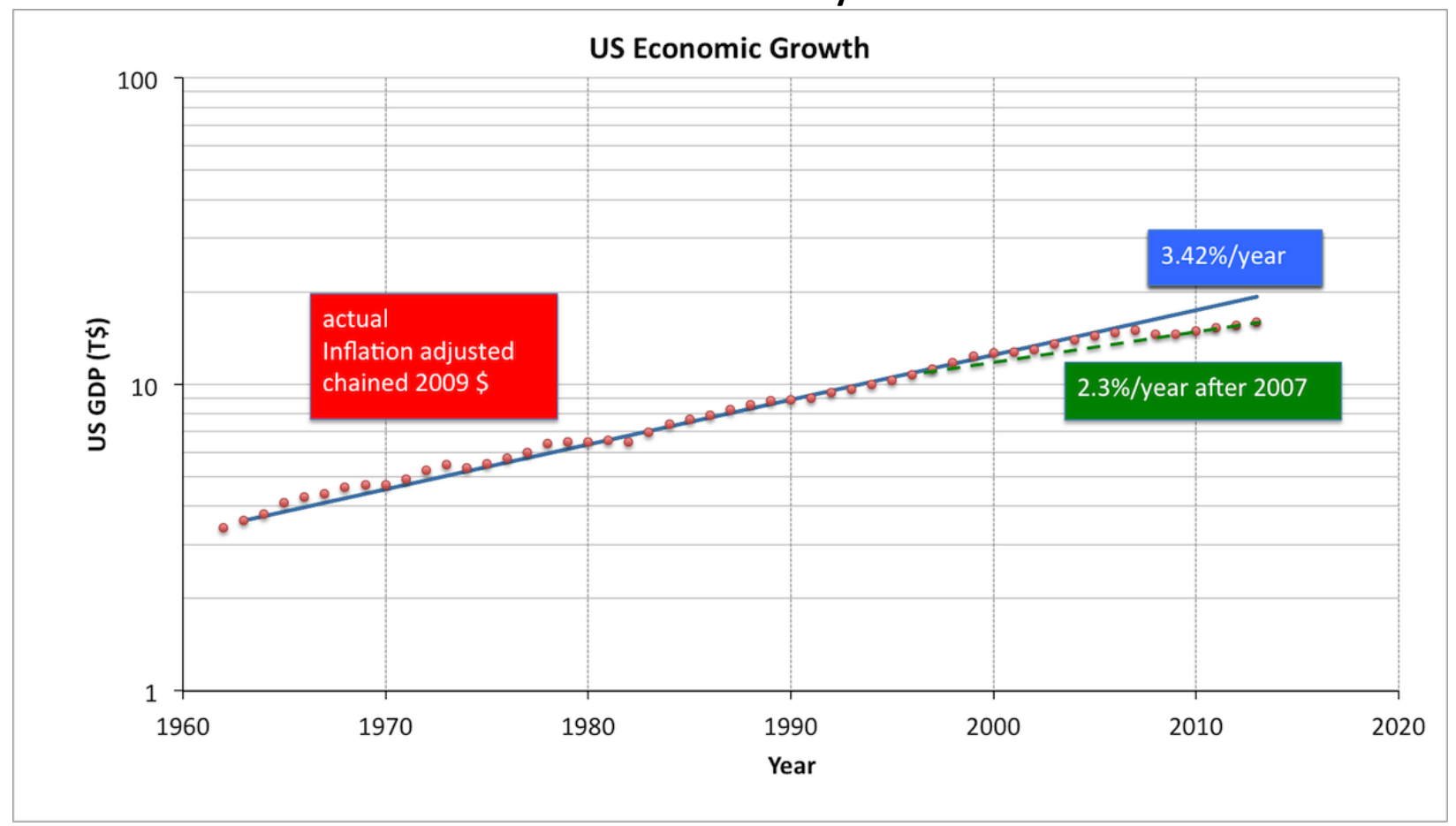

Perhaps patent trends are related to a more direct macroeconomic measure - research and development (R\&D) spending. In fact, however, that doesn't seem to be entirely true either. R\&D has been increasing since the 1950s, though with variations in the rate of increase. The growth rate of R\&D was highest in the late 1970s and early 1980s, when patents were weak and the number of patents was not growing dramatically, and in the late 1990s, when patents were strong and the number of patents was growing dramatically. R\&D expenditure leveled off in the early 1990s, when patents were getting stronger and the number of patents was growing, and again in the early 2000s, when patents were strong and the number of patents was growing. There seems to be a relationship between R\&D expenditure and the economy - R\&D expenditure leveled off during recessions - but not a clear relationship to substantive patent law or even to patenting behavior. 
To complicate the analysis, we might distinguish between public and private R\&D spending, as Figure 10 does. [It's not clear we should; public R\&D leads to patenting by universities]. ${ }^{122}$ But doing that doesn't change the result. Inflation-adjusted government R\&D spending has been roughly constant since the mid-1960s, so the variance is driven almost entirely by private industry R\&D expenditures.

122 The Bayh-Dole Act of 1980 encourages patenting by universities of federally-funded inventions in hopes of increasing technology transfer. See, e.g., Robin C. Feldman \& Mark A. Lemley, Patent Licensing, Commercialization, and Technology Transfer, 106 Am. Econ. Rev. _ (forthcoming 2016) (discussing technology transfer generated by universities). Whether it works is a matter of dispute. Compare Chester G. Moore, Killing the Bayh-Dole Act's Golden Goose, 8 Tul. J. Tech. \& Intell. Prop. 151 (2006) (arguing that patenting drives technology transfer) with Gary Pulsinelli, Share and Share Alike: Increasing Access to Government-Funded Inventions Under the Bayh-Dole Act, 7 Minn. J. L., Sci. \& Tech. 393 (2006) and Rochelle Dreyfuss, Pathological Patenting: The PTO as Cause or Cure, 104 Mich. L. Rev. 1559 (2006) (both expressing more skepticism). Cf. Ian Ayres \& Lisa Larrimore Ouellette, A Market Test for University Patents (working paper 2016) (proposing a mechanism to distinguish university patents that drive commercialization from those that don't). But whether or not it works, government R\&D funding is driving a significant increase in university patenting. See, e.g., DAVID C. MOWERY ET AL., IVORY TOWER AND INDUSTRIAL INNOVATION: UNIVERSITY-INDUSTRY TECHNOLOGY TRANSFER BEFORE AND AFTER THE BAYH-DOLE ACT 4 (2004); see generally John R. Allison et al., University Software Ownership: Trends, Determinants, Issues (working paper 2005, on file with author); Katherine J. Strandburg, Curiosity-Driven Research and University Technology Transfer, in UNIVERSITY ENTREPRENEURSHIP AND TECHNOLOGY TRANSFER: PROCESS, DESIGN, AND INTELLECTUAL PROPERTY 93 (Gary D. Libecap ed., 2005). Universities obtained 16 times as many patents in 2003 as they did in 1980. See Bernard Wysocki Jr., College Try: Columbia's Pursuit of Patent Riches Angers Companies, WALL ST. J., Dec. 21, 2004, at A1. 


\section{Figure 14}

\section{U.S. R\&D Funding by Source, 1953-2007 \\ expenditures in billions of constant 2007 dollars}

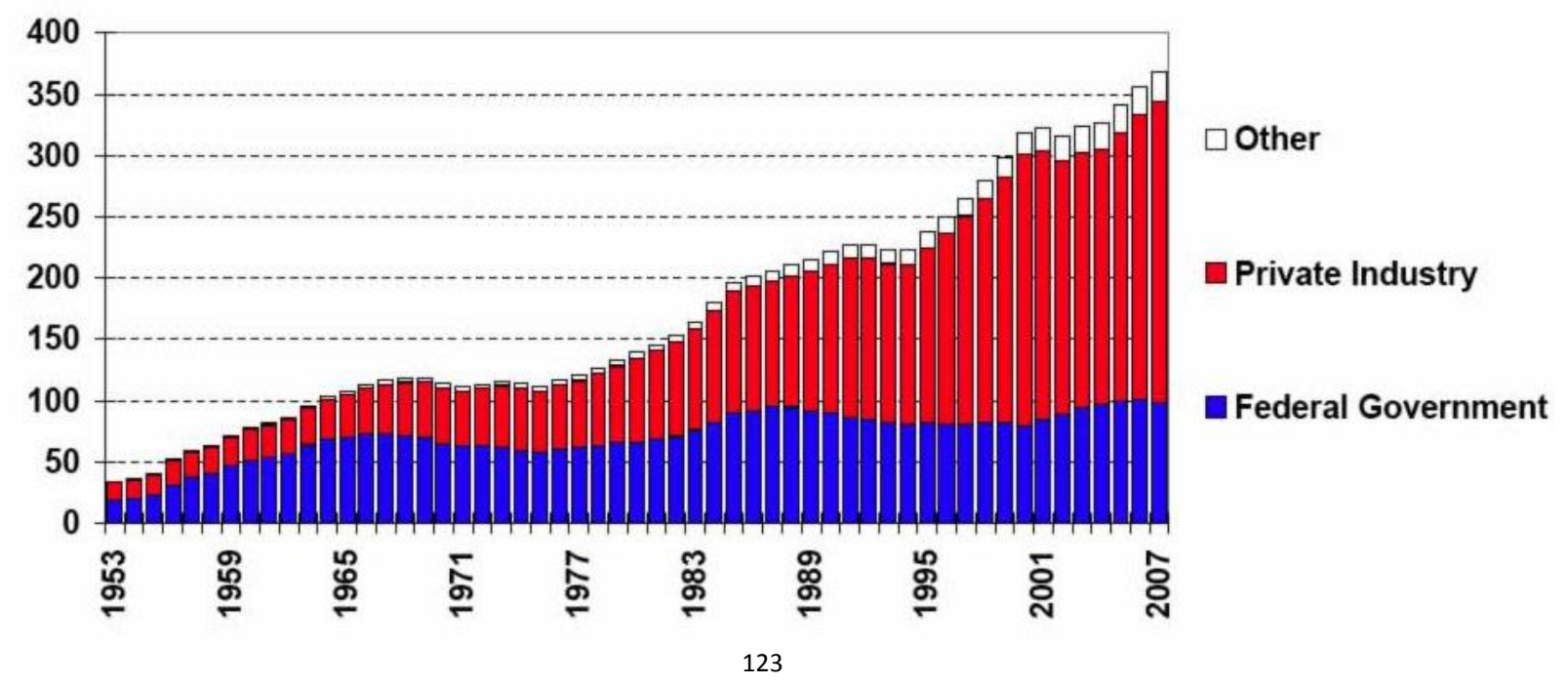

A second complication is that we might care about R\&D spending net of other intrinsic economic growth. [It's not clear that we should; none of our patent measures were GDPadjusted]. Figure 11 shows national R\&D expenditures as a percentage of R\&D. This does seem to track our assessment of patent merits in part. R\&D expenditure as a percentage of GDP declined in the 1970s, when patents were weak, and rose in the 1980s as patents got stronger. But the effect seems driven mostly by a decline in government, not private, expenditure. And private expenditure as a percentage of R\&D continued to grow through the 2000 s and into the 2010s, even as the substantive strength of patent law ebbed and flowed.

123 http://compbio.ucdenver.edu/hunter/cpbs7605/images/untitled.jpg 
Figure 15

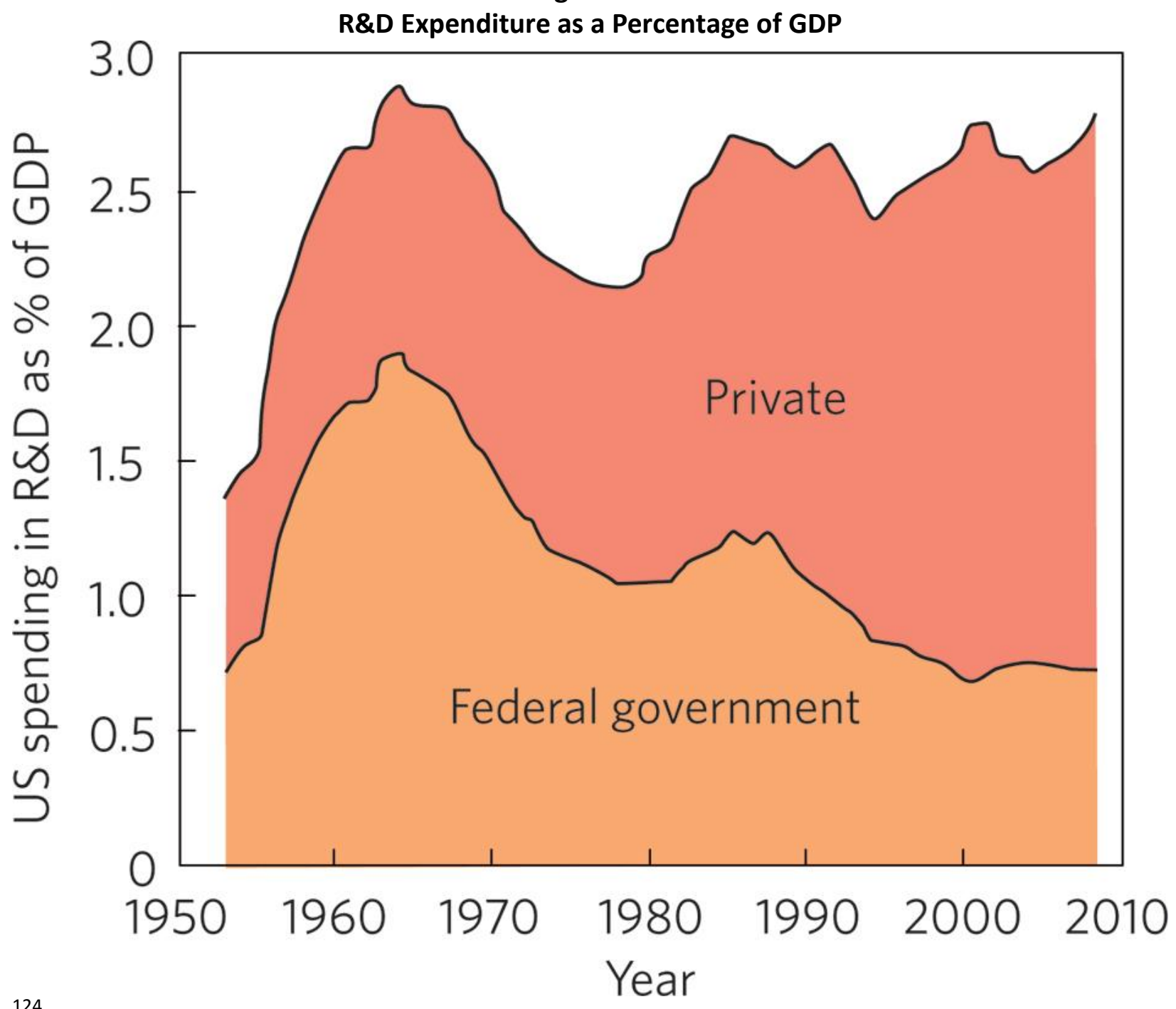

A final complication is that R\&D shouldn't translate immediately into patents. R\&D expenditure may only generate inventions some years later, patent applications later still, and issued patents several years later after that. So we might want to shift our curves to see if an investment now in R\&D results in patents five or ten years later. Even doing so, however, doesn't seem to align R\&D expenditure and the number of patents. On this theory we would have expected to see patent applications drop in the early 1980s, just when they begin to rise.

124 http://www.nature.com/nmat/journal/v10/n6/images/nmat3044-f1.jpg 
And the flattening of patent grants in the 2000 s doesn't seem to map to any lagged change in R\&D expenditure.

Additional evidence that R\&D expenditure is not a complete explanation for the resilience of the patent system comes from Colleen Chien, who finds that the number of patents per R\&D dollar not only varies by industry, but has changed substantially over time, dropping from one patent per $\$ 5$ million in R\&D expenditure in the IT industry to one patent per \$1 million in R\&D expenditure. By contrast, pharmaceutical patents per R\&D dollar fluctuate, but end up much where they started three decades before. 


\section{FIGURE 16 \\ R\&D (in \$M) per US Origin Patent Application1980-2007 (inflation adjusted)}

$\$ 7.00$

$\$ 6.00$

$\$ 5.00$

$\$ 4.00$

$\$ 3.00$

$\$ 2.00$

$\$ 1.00$

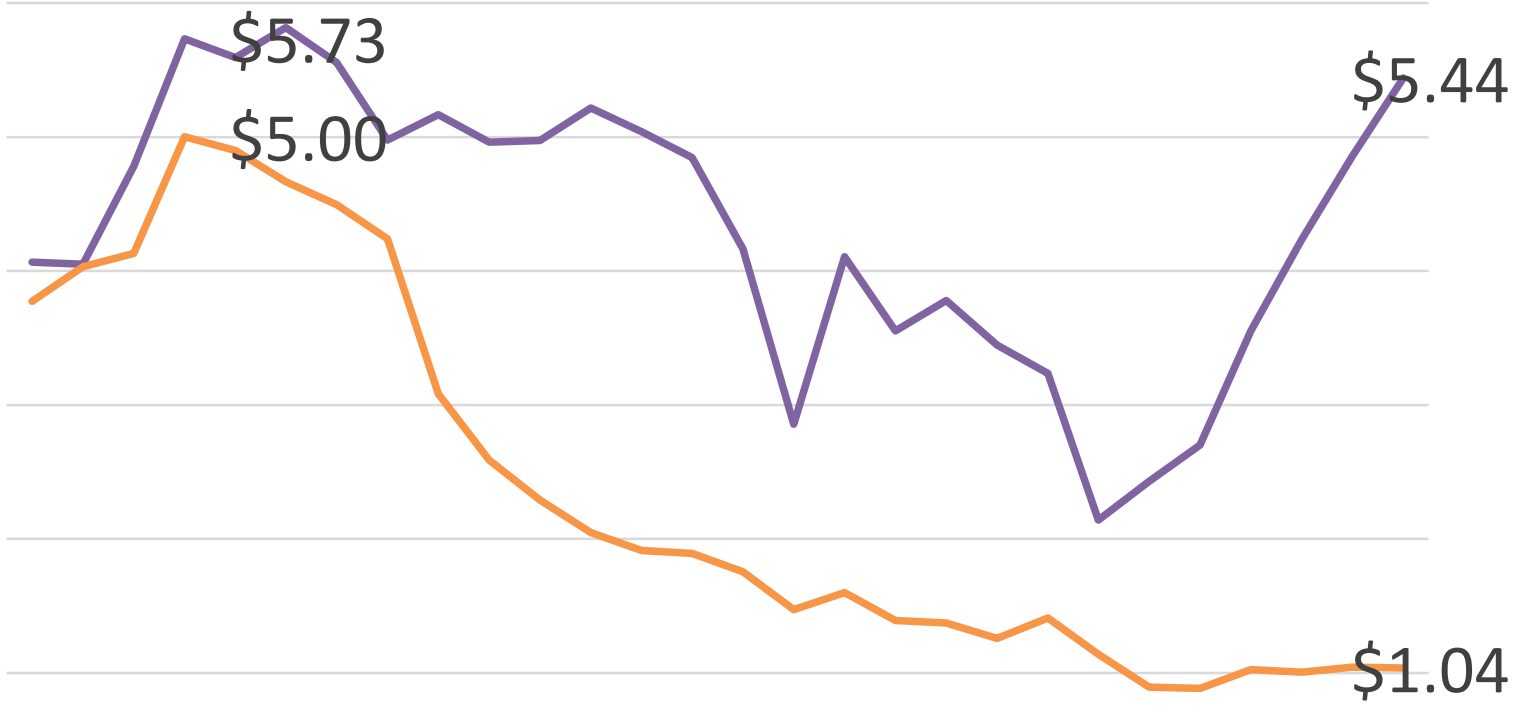

$\$-$

1980198419881992199620002004

-Chemicals -Electrical Equipment and Computers

125

Economic trends in general, and R\&D expenditures in particular, certainly should affect the use of the patent system. And I'm sure they do to some extent. But they don't seem to

125 Colleen Chien, Tom Cotter, \& Richard Posner, Patent Quality Levers (forthcoming 2016). 
explain the trends we see in patent applications or patent grants. Nor do they tell a clean story about the rise in patent litigation. ${ }^{126}$

\section{Do the Merits Matter? ${ }^{127}$}

Our puzzle remains a puzzle. Why do the fundamental characteristics of the patent system - both patent prosecution and patent litigation - seem largely insensitive to any of the variables that should affect them?

One final possible explanation is that the merits don't matter (or at least don't matter much) to the underlying dynamics of the patent system. Both patent prosecution and patent litigation have their own internal dynamics and justifications, and the reasons people file patents or patent lawsuits may not depend very heavily on the strength of patent rights - at least within limits.

\section{Patent Acquisition}

For patent acquisition, this explanation begins with a different puzzle, one long recognized in patent scholarship. While applicants obtain hundreds of thousands of patents per year, spending perhaps $\$ 20,000$ per application to do so, the vast majority of those patents then disappear from the system. ${ }^{128}$ A majority are abandoned for failure to pay maintenance

\footnotetext{
126 Marco et al., supra note _ , at _ (showing that patent litigation is both cyclical in part and countercyclical in part).

127 Cf. (very cf.) Janet Cooper Alexander, Do the Merits Matter? A Study of Settlements in Securities Class Actions, 43 Stan. L. Rev. 497 (1991) (finding that securities class actions settle for predictable amounts regardless of the strength of the suit).

128 Mark A. Lemley, Rational Ignorance at the Patent Office, 95 Nw. U. L. Rev. 1495 (2001).
} 
fees that are only a small fraction of the cost of obtaining the patent in the first place. ${ }^{129}$ And even the ones that are maintained mostly sit on a shelf. ${ }^{130}$ Only $1-2 \%$ of patents are ever litigated, and only a few percentage more are licensed for a royalty without ever being litigated. $^{131}$

Scholars have come up with a variety of theories for why people obtain patents and then do nothing with them. Perhaps patents are like lottery tickets, obtained for inventions that are mostly worthless in the hopes of hitting it big with an invention that does take off. ${ }^{132}$ Perhaps they are used as financing mechanisms, encouraging venture capital investment or acquisition. ${ }^{133}$ Perhaps they signal inventiveness or value to others. ${ }^{134}$ Perhaps they are marketing devices. ${ }^{135}$ Maybe they are vanity projects that make the inventor feel good about herself. ${ }^{136}$ Or they may be used by companies to encourage creativity, not in the expected way by providing economic incentives, but by measuring and rewarding creativity within

129 Id.; Kimberly A. Moore, Worthless Patents, 20 Berkeley Tech. L.J. 1521 (2005).

130 See Lemley, Rational Ignorance, supra note _, at _.

131 Id.

132 See, e.g., See F.M. Scherer, The Innovation Lottery, in Expanding the Boundaries of Intellectual Property 3-21 (Rochelle Dreyfuss et al. eds., 2001) (arguing that the possibility of supercompetitive returns to intellectual property may actually encourage overinvestment, just as people buy too many lottery tickets because they overstate the chance of a long-odds, high-value return); Dennis Crouch, The Patent Lottery: Exploiting Behavioral Economics for the Common Good, 16 Geo. Mason L. Rev. 141 (2008) (endorsing the lottery effect as a way to obtain new inventions more cheaply); Mark A. Lemley, What's Different About Intellectual Property?, 83 Tex. L. Rev. 1097 (2005) (decrying the lottery nature of IP rights).

133 See, e.g., Mark A. Lemley, Reconceiving Patents in the Age of Venture Capital, 4 J. Sm. \& Emerging Bus. L. 137 (2000); Mann, Financing, supra note _, at _; Stuart J.H. Graham \& Ted Sichelman, Why Do Start-Ups Patent?, 23 Berkeley Tech. L.J. 1063 (2008).

134 Clarisa Long, Patent Signals, 69 U. Chi. L. Rev. 625 (2002).

135 Ann Bartow, Separating Marketing Innovation from Actual Invention: A Proposal for a New, Improved, Lighter, and Better-Tasting Form of Patent Protection, 4 J. Sm. \& Emerging Bus. L. 1 (2000). 136 Id. 
organizations. ${ }^{137}$ Finally, as Dan Burk has argued, in the final analysis companies may patent because it is a social norm - something you do to show that you are in the club of responsible, innovative businesses. $^{138}$

What these alternative explanations for patenting have in common is that they don't depend very much on the substantive patent law or changes in the strength of patent rights. A company that patents because its peers or its venture capitalists expect it to won't care very much how easy it is to get an injunction after trial or whether plaintiffs who file frivolous suits may have to pay their adversary's attorneys' fees. They may care more about changes that affect patent validity, but only if those changes are so dramatic as to prevent them from patenting at all. And they rarely are. An inventor who wants a patent and is willing to narrow her claims can usually get one. ${ }^{139}$

We do see fluctuations in patent grant rates. But the best explanation for those fluctuations seems to be changes in attitudes at the PTO, not behavior by patent applicants. ${ }^{140}$ It is patent politics, not differences in the nature of inventions or research or the details of patent doctrine, that seems to drive patent filings and patent grants. That is consistent with

137 Stephanie Bair, The Psychology of Patent Protection, 48 Conn. L. Rev. 297 (2015).

138 Dan L. Burk, On the Sociology of Patenting (working paper 2016).

139 Lemley \& Sampat, supra note _ , at _ (finding that almost $3 / 4$ of applications result in at least one patent, and that most of the ones that don't were voluntarily abandoned for business reasons, not rejected by the PTO).

140 See supra notes ____ and accompanying text. Accord Katherine J. Strandburg et al., Patent Citation Networks Revisited: Signs of a Twenty-First Century Change?, 87 N.C. L. Rev. 1657 (2009) (finding based on patent citation networks that the PTO was laxer in issuing patents in the 1990s, but began tightening up its standards by 2000); Michael Frakes \& Melissa F. Wasserman, Patent Office Cohorts, 65 Duke L.J. _ (forthcoming 2016) (finding that the political environment at the PTO when an examiner was hired can influence her examination style and likelihood of granting patents, and that style persists even as administrations change). 
the hypothesis that the merits don't matter to most patent applicants. They file patent applications because they want patents. And in the aggregate, they seem to want patents without much concern for how strong those patents will be.

This doesn't mean, of course, that patent strength doesn't matter at all for patent acquisition. There is empirical evidence that changes in patent rules can have modest but statistically significant effects on who obtains patents and how many they obtain. ${ }^{141}$ David Abrams, for example, finds that the lengthening of effective patent terms when the U.S. adopted the 20-year patent term in 1995 led to increases in patenting in those industries that received longer patent terms. ${ }^{142}$ And Abrams and Polk Wagner find based on evidence from Canada that changes in who gets patents in a priority contest can change who applies for patents. ${ }^{143}$ Rather, the point is that the changes we have seen in the law in the past 40 years don't seem to have a major impact on either patent applications or patent issuance.

141 Indeed, Michele Boldrin and David Levine summarize the empirical evidence as finding "weak or no evidence that strengthening patent regimes increases innovation; [the empirical studies] find evidence that strengthening the patent regime increases ... patenting!" Michele Boldrin \& David Levine, Against Intellectual Monopoly 192 (2008).

142 David Abrams, Did TRIPS Spur Innovation? An Empirical Analysis of Patent Duration and Incentives to Innovate, 157 U. Pa. L. Rev. 1613 (2009). It is worth noting, however, that most patentees thought the result of TRIPs would be to reduce, not increase, patent term, leading many of them to file their applications before the law took effect. I predicted at the time that it would increase patent term, see Mark A. Lemley, An Empirical Analysis of the Twenty-Year Patent Term, 22 AIPLA Q.J. 369 (2014), and that turned out to be correct. See Carlos J. Serrano, The Dynamics of the Transfer and Renewal of Patents, http://papers.ssrn.com/sol3/papers.cfm?abstract id=1121730.

143 David Abrams \& R. Polk Wagner, Poisoning the Next Apple? The America Invents Act and Individual Inventors, 65 Stan. L. Rev. 517 (2013). Again, however, it is worth noting that what people believed would result from the move to first to file and what actually did were not the same. See Colleen V. Chien \& Mark A. Lemley, Are the U.S. Patent Priority Rules Really Necessary?, 54 Hastings L.J. 1299 (2003) (finding that small inventors did not in fact benefit from the old first-to-invent rules). In the TRIPs case, the realities of patent term seem to have trumped expectations, while in the first to file case the expectations seem to have trumped reality. 
Perhaps the explanation is just that the changes seem dramatic to a patent lawyer, but aren't actually all that significant in the overall scheme of things. A large enough change in patent rights might still affect patent acquisition. If the world were convinced patents were never enforceable, it is likely that fact would influence some of the non-enforcement justifications for obtaining patents. Venture capitalists might choose other measures of innovation prowess, and those who hold onto patents as lottery tickets One might argue that this was true in the 1970s, before the creation of the Federal Circuit. Evidence for this hypothesis comes from work by Josh Lerner and Petra Moser, both of whom find that strengthening IP rights from a very weak baseline can drive patenting behavior, but find less evidence of an effect once rights are already relatively strong. ${ }^{144}$ But if that is right, it suggests that while resilience has its limits, those limits are pretty forgiving. The changes we have seen in the past 40 years have had marginal effects, but not enough to change the basic trends in patent application and issuance.

\section{Patent Enforcement}

If you find it somewhat surprising that the merits don't seem to matter much to decisions to obtain patents, it should be all the more surprising that the merits don't seem to matter in patent litigation. While inventors may file patents for reasons that have little to do with their strength or enforceability in court, surely they file patent lawsuits because they hope to win and enforce those patents in court.

144 See, e.g., Josh Lerner, 150 Years of Patent Protection, http://papers.ssrn.com/sol3/papers.cfm?abstract id=179188; Petra Moser, Patent Laws and Innovation: Evidence from Economic History, http://papers.ssrn.com/sol3/papers.cfm?abstract id=2192804. 
But maybe not. We know that the overwhelming majority of patent lawsuits (85-90\%) settle before a merits decision. ${ }^{145}$ Even more settle after a ruling on summary judgment or at trial. ${ }^{146}$ While the Priest-Klein hypothesis is that those cases settle because the parties know who is likely to win, so the settlement is determined by the merits of the dispute, that may not always be true. Some - indeed, most - patent plaintiffs may file suit not because they hope the court will give them what they want, but because the act of filing a lawsuit itself may give them what they want, win or lose. Why might this be true? Consider four classes of cases.

First, some patent plaintiffs seek to use the high cost and uncertainty of patent litigation to coerce a nuisance-value settlement. These so-called "bottom feeder" patent plaintiffs ${ }^{147}$ know that litigating a patent case all the way to judgment can take $2-4$ years ${ }^{148}$ and cost over $\$ 5$ million on average in legal fees. ${ }^{149}$ They file suit against multiple defendants and then seek a quick settlement, often on the order of $\$ 50,000$ or $\$ 100,000$, sometimes more, but always less than the millions of dollars it would cost to defeat the patent in court. ${ }^{150}$ The bottom feeder model is profitable because it is rational for defendants to pay a small price to settle rather than pay a larger price to invalidate the patent. Invalidating the patent benefits their

145 See, e.g., John R. Allison et al., Patent Quality and Settlement Among Repeat Patent Litigants, 99 Geo. L.J. 677 (2011).

146 See Allison et al., Understanding the Realities, supra note _, at _ (noting that a significant percentage of patent cases settled while appear was pending).

147 Lemley \& Melamed, supra note _, at _.

148 See, e.g., Mark A. Lemley, Where to File Your Patent Case, 38 AIPLA Q.J. 401 (2010).

149 American Intellectual Property Law Association, Report of the Economic Survey 2015 at 30 (finding that large patent cases cost a median of $\$ 5.5$ million per side in legal fees to take to trial).

150 See, e.g, SFA Sys. v. Newegg, Inc., 793 F.3d 1344 (Fed. Cir. 2015) (considering a case involving such low-dollar, lump-sum settlements). To the extent it was relevant, I represented Newegg in that case. 
competitors, who can free ride on the service the challenger provided. ${ }^{151}$ Settling gets the challenger the same benefit at a fraction of the cost and without helping its competitors. ${ }^{152}$ We don't know how many cases fit the bottom feeder model, but it is a significant number. Nonpracticing entities represent more than $60 \%$ of patent lawsuits today, ${ }^{153}$ and bottom feeder suits are the most common type of troll suit. ${ }^{154}$

Second, at least some competitor cases are filed not because the patentee hopes to win in court, but because the very act of filing the lawsuit will disadvantage a competitor. Large companies can sometimes drive a small upstart competitor out of business by imposing litigation costs on them. I have personally represented companies that gave up and quit a business because they couldn't afford to continue fighting. Further, venture capitalists and acquisition partners are reluctant to fund a company being sued, both because of worries about whether the suit will shut the business down and because they don't want their money being spent on lawyers rather than engineers. ${ }^{155}$ Further, a patent lawsuit may scare off potential

151 Joseph Farrell \& Robert P. Merges, Incentives to Challenge and Defend Patents: Why Litigation Won't Reliably Fix Patent Office Errors and Why Administrative Patent Review Might Help, 19 Berkeley Tech. L.J. 943 (2004); John R. Thomas, Collusion and Collective Action in the Patent System: A Proposal for Patent Bounties, 2001 U. III. L. Rev. 305; Roger Ford, Patent Invalidity Versus Noninfringement, 99 Cornell L. Rev. 71 (2013).

152 To be sure, one risk of settling is that while the case before you is cheaper, other patent trolls may be more likely to sue you once they know you will pay them to go away. Some companies, like Newegg, have sought to develop a reputation for being unwilling to pay nuisance-value settlements. See Ivan Barajas, When Will Patent Trolls Learn Not to Mess with Newegg?, May 22, 2014, http://blog.newegg.com/patent-trolls-learn-mess-newegg/.

153 Miller, supra note _, at __.

154 Lemley \& Melamed, supra note _, at _.

155 See, e.g., Robin Feldman, Patent Demands and Startup Companies: The View from the Venture Capital Community (working paper 2013), available at http://papers.ssrn.com/sol3/papers.cfm?abstract id=2346338 (surveying venture capitalists and finding that " $100 \%$ of venture capitalists indicated that if a company had an existing patent demand against it, it could potentially be a major deterrent in deciding whether to invest); Catherine Tucker, The Effect of 
customers, particularly if (as often happens) the plaintiff notifies the customers of the suit or even sues the customers themselves. ${ }^{156}$ Even if it doesn't drive a company out of business altogether, a lawsuit represent a significant disruption to a growing business, taking business and engineering staff away from work to be deposed, search for documents, and testify. ${ }^{157}$ Ted Sichelman refers to this practice as "patent bullying." 158 It is hard to know how widespread it is, but it may be a significant factor in both cases in which large companies sue small start-ups and in which small companies sue their start-up competitors. Colleen Chien has found that these cases together account for $24 \%$ of patent lawsuits. ${ }^{159}$ And the sizeable number of default

Patent Litigation and Patent Assertion Entities on Entrepreneurial Activity (working paper 2014), available at http://papers.ssrn.com/sol3/papers.cfm?abstract id=2457611 (finding that litigation by patent trolls reduces VC investment in startups); Colleen V. Chien, Startups and Patent Trolls, 19 Stanford Tech. L. Rev. _ (forthcoming 2016), available at http://papers.ssrn.com/sol3/papers.cfm?abstract id=2146251.

156 See, e.g., Gaia Bernstein, The Rise of the End User in Patent Litigation, 55 B.C. L. Rev. 1443 (2014); Brian J. Love \& James C. Yoon, Expanding Patent Law's Customer Suit Exception, 93 B.U. L. Rev. 1605 (2013); Colleen V. Chien \& Edward Reines, Why Technology Customers Are Being Sued En Masse for Patent Infringement and What Can Be Done, 49 Wake Forest L. Rev. 235 (2014).

157 Cf Lemley \& Melamed, supra note _, at _ (discussing the dangers of competitor suits brought to harass competition).

158 Ted Sichelman, The Vonage Trilogy: A Case Study in "Patent Bullying," 90 Notre Dame L. Rev. 543 (2014).

159 Colleen V. Chien, Of Trolls, Davids, Goliaths, and Kings: Narratives and Evidence in the Litigation of High-Tech Patents, 87 N.C. L. Rev. 1571 (2009). Notably, the America Invents Act changed the rules in 2011 to prevent naming multiple defendants in the same lawsuit in most circumstances. The result was to increase the percentage of suits filed by patent trolls, who tend to sue many defendants at a time. See id. at $1571-72$ (noting that even in the mid-2000s, trolls accounted for $17 \%$ of suits but $36 \%$ of defendants sued). That number has increased since, and is now a majority by most counts (and depending on how one defines a patent troll). Christopher A. Cotropia, Jay P. Kesan, \& David L. Schwartz, Unpacking Patent Assertion Entities (PAEs), 99 Minn. L. Rev. 649 (2014) accord Colleen V. Chien, Patent Trolls by the Numbers (Santa Clara Univ. Legal Studies Research Paper No. 08-13, 2013), available at http://papers.ssrn.com/abstract=2233041; Robin Feldman, Tom Ewing \& Sara Jeruss, The AIA 500 Expanded: The Effects of Patent Monetization Entities, 17 UCLA J.L. \& Tech. 1 (2013) (finding that "patent monetization entities, yet another term for PAEs, filed $58.7 \%$ of the patent lawsuits); 
judgments and injunctions by consent decree suggest that this strategy is frequently effective. $^{160}$

Third, litigation between large companies with significant patent portfolios may not be motivated by a desire to win, but may instead be an extension of license negotiation by other means. When large companies sue other large companies, they run the risk that each may be held to infringe the other's patents. ${ }^{161}$ The result is a sort of mutually assured destruction that tends to deter those companies from taking their cases to judgment. ${ }^{162}$ Why then file suit at all? One reason may be that doing so signals seriousness in a license negotiation, and can bring a recalcitrant negotiating partner to the table or result in a more favorable license. These patentees aren't suing because they want to win, but because they want a business outcome somewhat more favorable than the one they would get without using litigation as a tool.

Finally, in the life sciences, the fact of filing a lawsuit can itself have significant regulatory effects on the ability of competitors to enter the market. Under the Hatch-Waxman Act, a patent plaintiff who sues a putative generic entrant is entitled to an automatic 30-month

160 Lex Machina data reports that as of February 27, 2016, 2,840 of the 47,364 terminated patent cases since 2000 , or $6 \%$, resulted in an entered consent or default judgment for the plaintiff. That probably significantly understates the number of defendants who cave in because they cannot afford to litigate a case to judgment, no matter how confident they are they would win. I have personally represented at least three such defendants in my litigation career.

161 An extreme example is patent litigation between Motorola and Hitachi in Texas in 1990. Each side sued the other for infringement of various patents. The district judge granted an injunction shutting down both parties' products. Needless to say, the parties quickly settled and asked the court of appeals to stay the injunctions while they did so. See Andrew Pollack, Motorola and Hitachi in Accord, N.Y. Times, June 26, 1990, http://www.nytimes.com/1990/06/26/business/motorola-and-hitachi-inaccord.html.

162 Gideon Parchomovsky \& R. Polk Wagner, Patent Portfolios, 154 U. Pa. L. Rev. 1 (2005); Allison et al., Valuable Patents, supra note _, at 468-69 ("The result is a sort of "mutually assured destruction" in which very few companies [in the semiconductor industry] actually sue for patent infringement because they know that, if they do, their opponents will also be able to sue them for patent infringement."). 
stay of the Food and Drug Administration's approval of the generic's application to enter the market. ${ }^{163}$ In effect, pharmaceutical and biotechnology companies can obtain an automatic preliminary injunction simply by filing a lawsuit, no matter how little merit the suit has. Even after that stay expires, generic companies are frequently reluctant to enter the market "at risk" until the patent lawsuit is resolved. The result is that patent lawsuits in the life sciences (which account for $25.3 \%$ of all suits) ${ }^{164}$ buy pharmaceutical and biotechnology patent owners years of insulation from competition whether or not they go to trial. Patent owners regularly seek to extend that advantage by paying their generic competitors to stay out of the market rather than litigating the case to judgment or by "product hopping" - switching formulations of their drug to take advantage of multiple 30 -month stays. ${ }^{165}$

What is notable about each of these strategies is that the patentee can get what they want - money, a competitive advantage, regulatory insulation from generic competition without ever taking the case to judgment. For that reason, changes in the strength of patent rights are largely irrelevant to all three classes of suit. As long as the fundamental economics of patent litigation remain unchanged, bottom feeders will use the system to collect nuisance-

16321 U.S.C. § 355(j)(5)(B)(iii). For criticism of this system, see, e.g., C. Scott Hemphill \& Mark A. Lemley, Earning Exclusivity: Generic Incentives and the Hatch-Waxman Act, 77 Antitrust L.J. 947 (2011).

164 Allison et al., Divided Patent System, supra note _, at _ (finding that $11.6 \%$ of suits are in the pharmaceutical industry, $10.5 \%$ in the medical device industry, and $3.2 \%$ in the biotechnology industry).

165 See, e.g., F.T.C. v. Actavis, Inc., 133 S.Ct. 2223 (2013) (holding reverse payment settlements potentially unlawful); New York ex rel. Schneiderman v. Actavis PLC, 787 F.3d 638 (2d Cir. 2015) (holding product-hopping unlawful). For discussions of product hopping, see, e.g., Stacey L. Dogan \& Mark A. Lemley, Antitrust Law and Regulatory Gaming, 87 Tex. L. Rev. 685 (2009); 1 Herbert Hovenkamp et al., IP and Antitrust $\S 15.2$ ( $2 \mathrm{~d}$ ed). For discussions of reverse payments, see, e.g., Michael A. Carrier, Unsettling Drug Patent Settlements: A Framework for Presumptive Illegality, 108 Mich. L. Rev. 37 (2009); Aaron Edlin, Scott Hemphill, Herbert Hovenkamp, \& Carl Shapiro, Activating Actavis, 28 Antitrust 16 (Fall 2013); C. Scott Hemphill, Paying for Delay: Pharmaceutical Patent Settlement as a Regulatory Design Problem, 81 N.Y.U. L. Rev. 1553 (2006); Herbert Hovenkamp, Mark D. Janis, \& Mark A. Lemley, Anticompetitive Settlement of Intellectual Property Disputes, 87 Minn. L. Rev. 1719 (2003). 
value settlements, bullies will use the system to impose costs on competitors, ${ }^{166}$ and big companies will use litigation as a form of license negotiation. As long as the regulatory framework stays the same, pharmaceutical plaintiffs will file patent suits no matter how weak the merits of the claim might be. For all of these reasons, most patent litigation, like most patent prosecution, may be driven by incentives to which the actual merits of the patent are only incidental.

But what of the small subset of cases that does go to judgment? The most difficult fact to explain about the resilience of the patent system is the unchanging nature of invalidity and overall patentee win rates. As noted above, I think selection effects can play some role here. Parties may choose to take different cases to trial or judgment in a world where patents are strong than where they are weak, creating an equilibrating tendency. But I don't think that's the whole explanation. A complementary possibility is that the subset of filed cases that go to judgment is essentially random. If patentees sue for reasons other than seeking a judgment, but can't cow their competitors or settle their disputes in ways that get what they want, their cases will go to trial or judgment not because of a conscious plan, but because the settlement didn't work out. If the selection of which cases make it to judgment is not conscious but largely an accident, it shouldn't surprise us that win rates don't vary that much with changes in patent doctrine. The percentages may reflect the long-term average of cases randomly (or at least 166 One important caveat concerns substantive changes to patent law that also affect the cost and
uncertainty of litigation. For instance, in the wake of the Supreme Court's decision in Alice Corp. Pty.
Ltd. v. CLS Bank Int'l, $134 \mathrm{~S}$.Ct. 2347 (2014), it not only became easier to invalidate certain software and
business method patents than it was before, but it also became possible to do so earlier in the litigation
process, often on a motion to dismiss. See, e.g., OIP Techs., Inc. v. Amazon.com, Inc., 788 F.3d 1359
(Fed. Cir. 2015); buySAFE, Inc. v. Google Inc., 765 F.3d 1350 (Fed. Cir. 2014). The possibility of winning a
case on an early motion before spending much money should change the incentive to file those cases
for process reasons, or at the very least should change how much money bottom feeders can demand. 
stochastically) selected for judgment: patents are held valid somewhat more often than not, whether because of the presumption of validity ${ }^{167}$ or because the PTO weeds out some bad patents. But the overall patentee win rate is low because of the fractioning of patent law: patent litigation involves multiple issues, and the patentee generally must win all of them to prevail in court. ${ }^{168}$

Again, my point is not that changes in the strength of patent laws could never have an effect on patent litigation patterns. After all, there was one fundamental shift in modern history - from a roughly $35 \%$ validity rate in the 1970 s to a $55 \%$ rate thereafter - that arguably was driven by substantive changes in patent law. ${ }^{169}$ And there is certainly evidence that outcomes on individual legal issues change as a result of changes in doctrine. ${ }^{170}$ Rather, the point is that however dramatic the changes in patent doctrine seem to those of us inside the system, they don't seem to be enough to change the overall dynamics of the system. As with patent acquisition, resilience may have its limits, but those limits seem to be pretty broad.

167 Microsoft Corp. v. i4i LP, 564 U.S. 91 (2011) (reaffirming that patents can be invalidated only on a showing of clear and convincing evidence); cf. Douglas Lichtman \& Mark A. Lemley, Rethinking Patent Law's Presumption of Validity, 60 Stan. L. Rev. 45 (2007) (arguing that that presumption is unwarranted).

This theory cannot explain why there was a long-term, significant increase in validity rates from the 1970 s to the modern era. Allison \& Lemley, Empirical Evidence, supra note _, at _.

168 Lemley, Fractioning, supra note _, at _.

169 Even that is open to question. It may be that the creation of the Federal Circuit changed the litigation dynamic significantly. Alternatively, it may be that procedural changes such as the rise of the jury trial in patent cases changed the validity results. Lemley, Why Do Juries Decide, supra note _, at

170 See, e.g., Christopher A. Cotropia, Nonobviousness and the Federal Circuit: An Empirical Analysis of Recent Case Law, _ Notre Dame L. Rev. _ (2009) (finding that KSR changed the willingness of the Federal Circuit to find patents obvious); Scott Flanz, Octane Fitness: The Shifting of Patent Attorneys' Fees Moves Into High Gear, cite. 


\section{Does Patent Law Matter?}

The most likely explanation for the surprising resilience of the patent system, then, is that the substantive and procedural changes we have seen in the last forty years simply don't matter much to the ordinary operation of patent law. That seems to be true with respect to the acquisition of patents, which occurs for reasons largely unrelated to the substantive law that would govern those patents were they to end up in court. More surprisingly, it seems to be true even of patent litigation, which is increasingly driven by economic factors that don't much depend on the substantive merits of patent law. As Tim Holbook and Mark Janis observe, the fact is that changes in legal doctrine, while theoretically designed to affect ex ante incentives, are largely unknown to or simply irrelevant to the way inventors and companies act in the real world. ${ }^{171}$

If I'm right in these explanations, what does that mean for the world? I can see three possible implications, which I will call the good, the bad, and the ugly.

\section{Good: The Sky Isn't Falling}

First, the good news: we are unlikely to break the patent system, whether by passing patent reform legislation or by failing to pass it. Much of the academic and policy debate over patent law in the past twenty years has focused on the relative dangers of overprotection and underprotection. Both sides have worried that changes to the patent system will kill the goose that laid the golden egg, retarding rather than promoting innovation. Those who worry about over protection fear that patent trolls will impose a tax on true innovators and that too many

171 Mark D. Janis \& Timothy J. Holbrook, Patent Law's Audience, 97 Minn. L. Rev. 72, 74075 (2012). 
strong patent rights will make cumulative innovation and bringing products to market harder. ${ }^{172}$ Those who (more recently) worry about underprotection tout the U.S. patent system as the primary reason for our national lead in innovation, and fear that weakening that system will discourage invention and prevent good ideas from getting to market. ${ }^{173}$

The evidence, however, suggests that both of these concerns are overblown. Radical changes in both patent substance and procedure that strengthened the hand of patent owners during the 1980s and 1990s and brought us a deluge of patent trolls didn't break the patent system, worries about the patent crisis notwithstanding. Indeed, they didn't seem to have a significant causal effect on patent applications, patent grants, patent lawsuits, or patent judgments.

By the same token, the more recent reforms to the patent system weakening patent rights will also not break the patent system. Indeed, those reforms too don't seem to have much changed the ever-increasing number of patent applications, patent grants, or patent lawsuits. Nor have they reduced patentees' win rate in court or the damage awards they receive when they do win. We don't, of course, know whether the courts and Congress will continue to cut back on the power of patent owners. There is some reason to think the pendulum is slowing down. ${ }^{174}$ But previous changes to the substance of patent law haven't derailed the patent system. Indeed, they haven't even changed its momentum very much. The

\footnotetext{
172 See supra notes _-_ and accompanying text.
}

173 See supra notes ____ and accompanying text.

174 See supra note _ (discussing the collapse of patent reform efforts in 2014 and 2015). The Supreme Court, which has reliably sided with accused infringers for over a decade, has recently issued a string of decisions that support the patent owner. Microsoft, 564 U.S. at 91; Commil USA, Inc. v. Cisco Sys., Inc., 135 S.Ct. 1920 (2015); Global-Tech Appliances, Inc. v. SEB S.A., 563 U.S. 754 (2011). And it may do the same in its most recent patent cases, argued February 23. 
same is likely to be true for the foreseeable future. The good news, then, is that the sky isn't falling. We aren't about to destroy the patent system or halt innovation.

That doesn't mean, of course, that nothing we do could destroy (or dramatically improve) the patent system. Perhaps it simply means we haven't been trying hard enough. Some might contest the claim that the changes we have made to the patent system in the last forty years are as dramatic as I suggest. One could imagine more radical changes - a working requirement for patents, or excluding software entirely from patent protection, for instance. ${ }^{175}$ We haven't tried those things, so we don't know how the system would react. There may well be limits to the resilience of the system, so that too strong or too weak protection could knock the system out of equilibrium. But the sorts of change we have seen in the last several decades, significant as they seem to patent lawyers, don't seem radical enough to bump the patent system out of its established track.

\section{Bad: Why Bother With Patent Reform?}

It's good to learn that we are unlikely to destroy the patent system or stop the flow of innovation by passing patent reform, or by failing to pass it, or indeed by doing anything else we are likely to do to change the substantive nature of patent law. But it's also a bit depressing. As someone who has devoted my life to the study of IP law and to figuring out ways to improve it, I confess that the resilience of the patent system can sometimes seem like a personal affront - the universe saying to those of us who study patent law, in effect, "nothing you do matters very much."

175 Or, on the pro-patent side of the ledger, longer patent terms, punitive damages without willful infringement, or limits on the ability to challenge the validity of patents. 
That should probably worry more than just people like me who might feel like we can't effect change. Perhaps the lesson is simply that big institutions have a lot of inertia, so it's hard to change their direction. But I don't think the issue here is simply that the policy changes in one direction or another have simply been too small to have a measurable effect. Rather, patent institutions seem to have taken on a life of their own, one largely beyond the reach of the policy levers we employ to try to calibrate innovation incentives. The same may be true of litigation. A strong legal realist theory might conclude that legal doctrines don't matter for case outcomes because judges and juries pick who they want to win regardless of what the law says. That could explain the lack of change in litigation outcomes. And if patentees only care about winning, and they are just as likely to win as they were ten or twenty years ago, all the changes in legal doctrine don't matter in the final analysis.

That doesn't mean changes in the law have no effect at all, of course. They change the cost of litigation, and they change who can obtain a patent and whether that patent can be enforced. Changing outcomes for individual inventors and manufacturers is certainly relevant for the parties involved. And there may be a Platonic sense in which we want to get the right outcome for its own sake, both in individual cases and in the overall balance of the system. But it seems that what we think we are doing when we make patent policy - aligning incentives in order to better promote innovation - happens only at the margins, if at all. It may not affect behavior because it doesn't much affect what people get out of the system.

\section{Ugly: Why Patent At All?}


Whether you think that is good or bad may depend on how you feel about the patent system in its current form. As I have noted elsewhere, persuasive evidence that the patent system drives innovation is surprisingly hard to come by. ${ }^{176}$ Some have suggested that it works well in some industries and poorly in others. ${ }^{177}$

The problems with a patent system seemingly impervious to our efforts to manipulate it may go beyond frustration with our inability to effectuate policy levers (or, for those of us who write about patent policy, inability to justify our existence). The patent system is not handed down from on high by some benevolent deity. It is government regulatory policy: an effort to intervene in the free market in order to encourage more invention than we would otherwise have. ${ }^{178}$ But if that policy is a good idea, we would expect changes in it to have some measurable effect, if not on innovation directly, at least on the behavior of patent owners and accused infringers. After all, the whole point of the system is to tweak incentives to innovate. If, as it seems, the patent system has taken on a life of its own independent of efforts to manipulate it, it is worth asking what good it is doing for society to have the system at all. Is it just another government bureaucracy that exists because it has always existed? A system we

176 Mark A. Lemley, Faith-Based IP, 62 UCLA L. Rev. 1328 (2015).

177 James Bessen \& Michael J. Meurer, Patent Failure: How Judges, Bureaucrats and Lawyers Put Innovation at Risk (2008) (arguing that patents enhance social welfare only in the chemical and biomedical industries, not elsewhere). Cf. Dan L. Burk \& Mark A. Lemley, The Patent Crisis and How the Courts Can Solve It (2009) (noting the industry-specific nature of innovation and the patent system). 178 Shubha Ghosh, Decoding and Recoding Natural Monopoly, Deregulation, and Intellectual Property, 2018 U. III. L. Rev. 1125; Shubha Ghosh, Patents and the Regulatory State: Rethinking the Patent Bargain Metaphor After Eldred, 19 Berkeley Tech. L.J. 1315 (2004); Mark A. Lemley, The Regulatory Turn in IP, 36 Harv. J. L. \& Pub. Pol'y 109 (2013); Mark A. Lemley, Taking the Regulatory Nature of IP Seriously, 92 Tex. L. Rev. See Also 68 (2014); Ted Sichelman, Purging Patent Law of Private Law Remedies. 92 Tex. L. Rev. 517 (2014). 
keep around, not because the evidence supports it, but because it has become an article of faith $?^{179}$

I think the evidence I discussed above provides a partial answer to this concern. Patent applications may be driven by economic considerations almost entirely independent of the enforceability of the resulting patents. And those patents may in turn facilitate venture financing or technology transfer. ${ }^{180}$ If we step back and think about it, it seems a bit odd that people would transact on the basis of patents without regard to the intrinsic value of those patents, but in some sense many markets, from tulips to gold to the stock market, share that

179 See Mark A. Lemley, Faith-Based IP, 62 UCLA L. Rev. 1328 (2015). To be sure, there are nonconsequentialist theories of patent law. See, e.g, Robert P. Merges, Justifying Intellectual Property (2011). Cf. Amy Kapczynski, The Cost of Price: Why and How to Get Beyond Intellectual Property Internalism, 59 UCLA L. Rev. 970 (2012) (arguing against exclusive reliance on price, though not necessarily consequentialism). If one subscribes to one of those theories [I do not], I suppose it wouldn't matter whether patents were serving a useful end. The existence of the patent right could be viewed as an end in itself.

180 Ashish Arora, Markets for Technology (2001); Feldman \& Lemley, Commercialization, supra note at _.

New institutional economics theory suggests that patents may affect transactions, causing individuals to organize either within or outside firms depending on the scope of ownership rights. See, e.g., Robert P. Merges, Intellectual Property Rights and the New Institutional Economics, 53 Vand. L. Rev. 1857 (2000); Robert P. Merges, A Transactional View of Property Rights, 20 Berkeley Tech. L.J. 1477 (2005); Dan L. Burk, Intellectual Property and the Firm, 71 U. Chi. L. Rev. 3 (2004); Johnathan M. Barnett, Intellectual Property as a Law of Organization, 84 S. Cal. L. Rev. 785 (2011). Cf. Jonathan S. Masur, Patent Liability Rules as Search Rules, 78 U. Chi. L. Rev. 187 (2011) ("Patent liability rules determine not only who will be responsible for what conduct, but also when patent holder and potential infringers will benefit from locating (or remaining ignorant of) one another."). Whether increasing the number of transactions is itself desirable is a contested proposition, however. See Michael J. Burstein, Patent Markets: A Framework for Evaluation, 47 Ariz. St. L.J. 507 (2015); Robert P. Merges, The Trouble with Trolls: Innovation, Rent-Seeking, and Patent Law Reform, 24 Berkeley Tech. L.J. 1583, 1583 (2009) ("The presence of willing buyers and willing sellers does not necessarily imply that social welfare is being served; at times, the legal system must shut down markets when the things being exchanged have no social value"). As Rochelle Dreyfuss notes, "The result is a vicious cycle. The better patents are at protecting investments in innovation, the more firms rely on patents; the more evident it is that patents are good sources of income, the more they are used as investment vehicles. As the thicket of rights grows, it becomes harder to maneuver without attracting litigation. Since the best defense is often a good offense, firms patent to the hilt, creating a base for even more suits." Dreyfuss, Pathological, supra note _, at 1562. 
fundamental characteristic. There is no underlying intrinsic value for which people are paying; the asset is valuable because, and only to the extent that, people think it is valuable. ${ }^{181}$ That probably ought to make us worry about the stability of any of those markets, but most of them, including patents, have shown a fair bit of stability over the past several decades. ${ }^{182}$ And if the market values patents for patents' sake, using them as markers of innovation or trading chits, we ought to be hesitant to disrupt that value by eliminating the patent system, even as we seemingly need not worry too much about disrupting that value by making changes to the patent system.

The same cannot be said for patent litigation, however. Obtaining patents in order to use them as market assets might be socially beneficial and in any event is largely costless to third parties. Suing third parties, by contrast, is not. Of the four reasons people litigate patent cases other than to win on the merits, three (nuisance-value settlements, bullying, and regulatory gaming) are actively socially harmful. The patent litigation system imposes substantial costs on third parties, and most of those third parties are themselves innovators. It may be worth paying those costs if there is evidence that patent litigation is supporting new invention. But absent that evidence, the patent litigation system looks more and more like a drag on society. Sure, it generates patent licenses in the form of settlements of lawsuits. But in the absence of technology transfer, those licenses are not beneficial to society. ${ }^{183}$ And there

181 Timothy Knight, Panic, Prosperity, and Progress: Five Centuries of History and the Markets (2014).

182 Tulips, by contrast, are likely not coming back anytime soon. Id. at 1-7.

183 Feldman \& Lemley, Commercialization, supra note _, at __; Michael J. Burstein, Patent Markets: A Framework for Evaluation, 47 Ariz. St. L.J. 507 (2015). 
doesn't seem much evidence in most industries that the ability to enforce a patent in court translates into greater invention or innovation. ${ }^{184}$

That doesn't mean we can just get rid of patent litigation. First, there are circumstances like enforcement of primary pharmaceutical patents in which it does seem to support innovation incentives. ${ }^{185}$ Second, the ultimate threat to enforce a patent, however divorced from reality, may be what is propping up the market for technology transfer based on patents. Finally, the existence of the litigation system may prevent unproductive copying of inventions. The majority of patent suits today are filed by companies who are not themselves practicing the patent, ${ }^{186}$ and the vast majority of patent suits are filed not against alleged copiers, but against defendants who invented the technology independently of the patentee. ${ }^{187}$ But the fact that copying of inventions is rare today doesn't mean it would be if we had no patent litigation system. It may be the threat of patent litigation itself that deters copying. ${ }^{188}$ As noted above, while the system is resilient to a surprising array of changes, that doesn't mean it always will be.

184 The pharmaceutical industry is an important exception. Bessen \& Meurer, supra note _, at _ (finding that the patent system confers net social benefits only in the life sciences).

185 I distinguish here between patents on a truly new chemical entity and the sort of secondary patents that are used primarily to game the regulatory system. C. Scott Hemphill \& Bhaven Sampat, When Do Generics Challenge Drug Patents?, 8 J. Empirical L. Stud. 613 (2011); C. Scott Hemphill \& Bhaven Sampat, Evergreening, Patent Challenges, and Effective Market Life in Pharmaceuticals, $31 \mathrm{~J}$. Health Econ. (2012). The former may provide needed incentives to invent, or at least to invest in the FDA regulatory process. Benjamin N. Roin, Unpatentable Drugs and the Standards of Patentability, 87 Tex. L. Rev. 503 (2009). The latter generally do not.

186 See supra note _.

187 Cotropia \& Lemley, supra note _..

188 See Mark A. Lemley, Should Patent Infringement Require Proof of Copying?, 105 Mich. L. Rev. 1525 (2007). 


\section{E. Patent Reform for a System that Ignores Patent Reform}

Maybe it's just my optimistic nature, but I am inclined to see the good, not the bad or the ugly, in these numbers. While the temptation is strong to throw up one's hands and give up on making the system better, or even give up on the system itself, I think the very resilience of the patent system offers opportunities to improve it. While we may not want to get rid of patent litigation for the reasons just noted, for instance, the evidence suggests that we need not be wedded to any particular aspect of that system, precisely because the patent system as a whole is resilient to efforts to change it. Based on recent history, we shouldn't expect changes to patent litigation to move the needle very much one way or the other when it comes to encouraging or discouraging innovation. But for that reason, a number of changes that reduce the social cost of patent litigation can probably be made at little or no cost to innovation incentives.

The resilience of the patent system may therefore offer new prospects for patent reform that avoid traditional tradeoffs between the benefits of stronger and weaker protection. ${ }^{189}$ Thus, we should look out for opportunities to simplify patent litigation, making it quicker and cheaper. We may also want to take some cases out of the litigation system altogether. Suits by non-practicing entities against defendants who independently invented the technology, for instance, don't seem necessary to facilitate patent markets, and they may impose a substantial cost on innovation. We may be better off without them. ${ }^{190}$ Finally, we

189 Cf. Golden, supra note _, at _ (discussing a "dual-ratio" test to try to identify reforms that do not simply increase or decrease patent protection).

190 Samson Vermont, Independent Invention as a Defense to Patent Infringement, 105 Mich. L. Rev. 475 (2006); Carl Shapiro, Prior User Rights, 96 Am. Econ. Rev. 92 (2006); Feldman \& Lemley, Commercialization, supra note _, at __ Oskar Liivak, Rethinking the Concept of Exclusion in Patent Law, 
might change the remedial structure of patent law in a way that reduces the costs of the system without much affecting incentives to invent or commercialize. ${ }^{191}$

The surprising resilience of the patent system, then, might lead us to question why we need particular patent litigation rules. That may in turn point the way to patent reforms. Those reforms most likely won't achieve our long-standing goal of improving incentives to invent, either by strengthening or weakening patent protection. But precisely for that reason, reforms targeted at unproductive litigation behavior might reduce the cost of the patent system without doing much harm. In a system that seems largely impervious to our efforts to improve it, that may be the best we can hope for.

98 Geo. L.J. 1643 (2010). Cf. Lemley, Proof of Copying, supra note _, at _ (noting the attractiveness of an independent invention defense but offering some cautions).

191 See, e.g., John F. Duffy, Reviving the Paper Patent Doctrine, 98 Cornell L. Rev. 1359 (2013); Merges, Trolls, supra note __, at _; Sichelman, Remedies, supra note __, at _. 